\title{
Article \\ Comparative Analysis of Erosive Wear Behaviour of Epoxy, Polyester and Vinyl Esters Based Thermosetting Polymer Composites for Human Prosthetic Applications Using Taguchi Design
}

\author{
Jeetendra Mohan Khare ${ }^{1}$, Sanjeev Dahiya ${ }^{1}$, Brijesh Gangil ${ }^{2}$, Lalit Ranakoti ${ }^{3}$, Shubham Sharma ${ }^{4, *(D)}$, \\ Muhammad Roslim Muhammad Huzaifah 5,*(D), Rushdan Ahmad Ilyas 6,7 (D), Shashi Prakash Dwivedi 8 , \\ Somnath Chattopadhyaya ${ }^{9}$ (D), Huseyin Cagan Kilinc ${ }^{10}$ and Changhe Li $^{11}$ (D)
}

check for updates

Citation: Khare, J.M.; Dahiya, S.; Gangil, B.; Ranakoti, L.; Sharma, S.; Huzaifah, M.R.M.; Ilyas, R.A.; Dwivedi, S.P.; Chattopadhyaya, S.; Kilinc, H.C.; et al. Comparative Analysis of Erosive Wear Behaviour of Epoxy, Polyester and Vinyl Esters Based Thermosetting Polymer Composites for Human Prosthetic Applications Using Taguchi Design. Polymers 2021, 13, 3607. https:// doi.org/10.3390/polym13203607

Academic Editors: Emin Bayraktar, S M. Sapuan and R. A. Ilyas

Received: 25 September 2021

Accepted: 15 October 2021

Published: 19 October 2021

Publisher's Note: MDPI stays neutral with regard to jurisdictional claims in published maps and institutional affiliations.

Copyright: (C) 2021 by the authors Licensee MDPI, Basel, Switzerland. This article is an open access article distributed under the terms and conditions of the Creative Commons Attribution (CC BY) license (https:/ / creativecommons.org/licenses/by/ $4.0 /)$.
1 School of Engineering \& Technology, University of Technology, Rajasthan, Jaipur 303903, India; jmkhare2010@gmail.com (J.M.K.); dahiyasanjeev764@gmail.com (S.D.)

2 Department of Mechanical Engineering, H.N.B. Garhwal University, Garhwal, Srinagar 246174, India; brijeshgangil7@gmail.com

3 Department of Mechanical Engineering, National Institute of Technology (NIT Uttarakhand), Srinagar 246174, India; lalitranakoti9000@gmail.com

4 Department of Mechanical Engineering, IK Gujral Punjab Technical University, Main Campus, Kapurthala 144603, India

5 Department of Crop Science, Faculty of Agricultural Science and Forestry, Universiti Putra Malaysia Bintulu Campus, Bintulu 97000, Malaysia

6 School of Chemical and Energy Engineering, Faculty of Engineering, Universiti Teknologi Malaysia, Johor Bahru 81310, Malaysia; ahmadilyas@utm.my

7 Centre for Advanced Composite Materials, Universiti Teknologi Malaysia, Johor Bahru 81310, Malaysia

8 G.L. Bajaj Institute of Technology \& Management, Greater Noida 201310, India; spdglb@gmail.com

9 Department of Mechanical Engineering, Indian Institute of Technology (ISM) Dhanbad, Dhanbad 826004, India; somnathchattopadhyaya@iitism.ac.in

10 Civil Engineering Department, Istanbul Esenyurt University, Istanbul 34510, Turkey; huseyincagankilinc@esenyurt.edu.tr

11 School of Mechanical and Automotive Engineering, Qingdao University of Technology, Qingdao 266520, China; sy_lichanghe@163.com

* Correspondence: shubham543sharma@gmail.com or shubhamsharmacsirclri@gmail.com (S.S.); muhammadhuzaifah@upm.edu.my (M.R.M.H.)

Abstract: In polymer composites, synthetic fibers are primarily used as a chief reinforcing material, with a wide range of applications, and are therefore essential to study. In the present work, we carried out the erosive wear of natural and synthetic fiber-based polymer composites. Glass fiber with jute and Grewia optiva fiber was reinforced in three different polymer resins: epoxy, vinyl ester and polyester. The hand lay-up method was used for the fabrication of composites. $\mathrm{L}_{16}$ orthogonal array of Taguchi method used to identify the most significant parameters (impact velocity, fiber content, and impingement angle) in the analysis of erosive wear. ANOVA analysis revealed that the most influential parameter was in the erosive wear analysis was impact velocity followed by fiber content and impingement angle. It was also observed that polyester-based composites exhibited the highest erosive wear followed by vinyl ester-based composites, and epoxy-based composites showed the lowest erosive wear. From the present study, it may be attributed that the low hardness of the polyester resulting in low resistance against the impact of erodent particles. The SEM analysis furthermore illustrates the mechanism took place during the wear examination of all three types of composites at highest fiber loading. A thorough assessment uncovers brittle fractures in certain regions, implying that a marginal amount of impact forces was also acting on the fabricated samples. The developed fiber-reinforced polymer sandwich composite materials possess excellent biocompatibility, desirable promising properties for prosthetic, orthopaedic, and bone-fracture implant uses.

Keywords: natural and synthetic fibers; thermosetting polymers; $\mathrm{L}_{16}$ orthogonal array; Taguchi method; erosion mechanism; SEM analysis; prosthetic applications 


\section{Introduction}

Fiber-reinforced polymer composite materials are the modern materials applied in various applications such as automobile interiors, construction articles, transportation materials, packaging, and household ware [1-3]. The prerequisite necessary for all the aforementioned applications is good strength, stiffness, durability, flexibility, etc., which a composite does exhibits as reported by several literatures in the past decades [4-6]. Synthetic fiber-reinforced polymer composites have several advantages such as extremely high strength comparable to metals but have several demerits such as high carbon release in the environment, non-disposable leading to soil degradation, high cost, etc. [7]. On the other hand, natural fiber reinforced polymer composites exhibit quite remarkable mechanical properties but far lower than synthetic counterparts [8-10]. To optimize parameters such as strength, cost, etc., and minimize the hazardous environmental effects, hybridization of natural and synthetic fiber has been performed. For instance, the hybrid composite was prepared by incorporating Cocos nucifera and Lufa cylindrical fiber at a weight fraction of $30 \%$ in the mix of MEKP and cobalt naphthenate and reported that mechanical properties improved by $31 \%$. It was also reported that changing the fiber ratio in the composition led to alteration of property from ductile to brittle [11]. The addition of cellulosic fiber (banana, abaca, jute, and hemp, wood) in glass fiber reinforced polymer hybrid composite yields higher mechanical strength than composite containing only glass fiber [12-14]. Analysis of the hybrid composite of synthetic-synthetic fiber [15] and plant-animal fiber $[16,17]$ have also been carried out and reported improved results regarding mechanical properties. Kevlar-kenaf fiber reinforced polymer hybrid composite was fabricated to investigate mechanical properties $[18,19]$ and reported that significant enhancement can be obtained in the impact properties at $40 \mathrm{wt} \%$ of fiber reinforcement. Automobile door panels and several automotive parts are under consideration to be manufactured from the hybrid composite of hemp and kenaf fiber [20].

Glass fiber is one of the strongest known fiber primarily used as a chief reinforcing material in the polymer composite with a wide range of applications. However, due to its high cost, several natural fibers were reinforced to make the composite economic. In addition, glass fiber is highly brittle and, therefore, mostly reinforced with ductile natural fiber to reduce the brittleness of hybrid polymer composite [21]. In recent times, various natural fibers have been reinforced with glass fiber to enhance the mechanical properties and wear resistance of glass fiber polymer composite. For instance, reinforcement of fibers such as bamboo, sisal, and wood in glass fiber composite enhanced tensile, flexural, and impact properties of hybrid composite [22-24]. Silica nanoparticles filled glass fiber reinforced epoxy composites yield five times higher fatigue strength than virgin glass fiber composite [25]. Fracture strength, interlaminar shear strength, flexural strength, and impact strength were improved by incorporating flax, basalt, and jute fiber in glass fiber reinforced polymer composite [26-29]. It has been observed that the weightage of natural fiber was kept below the weightage of glass fiber in the hybrid composite to obtain optimum mechanical strength [30-32]. The mechanical and tribological properties of a hybrid composite comprising more than two fibers, primarily two natural and one glass fiber, were also investigated. In this regard, glass fiber/sisal fiber/chitosan reinforced polymer sandwich were fabricated for orthopaedic fracture application and reported impressive wear resistance and modulus [33]. Hybridization of $10 \%$ jute and $10 \%$ tea leaf fiber in glass yielded mechanical strength of such value that can even replace virgin glass fiber composite [34]. Reinforcing jute, sisal, kenaf, or combining the two in glass fiber reinforced polymer composites also improves the mechanical properties. [35,36].

Material erosion caused by hard particles is one of several types of material degradation categorized as wear. Polymers composites also work under different working conditions, requiring an analysis of their wear activities before they are located in a real environment. Several studies have been reported in the past for the investigation of erosive wear of polymer composite containing different types of fiber and fillers [37]. For instance, glass fiber reinforced polymer composite filled with micro silica and zinc oxide was fabri- 
cated via vacuum-assisted method and investigated for erosive wear behavior at a different impingent angle ranging from $20^{\circ}$ to $90^{\circ}$ [38]. It was reported that silica fumes enhanced the composite's erosive wear resistance, while zinc oxide promoted erosive wear.

Moreover, increasing the impingement angle and size of erodent particles increased the erosive wear. The incorporation of marble dust in glass fiber reinforced polymer composite reduces erosive wear of the fabricated composite, as marble dust increases the hardness and stiffness of the composite surface [39]. Diversifying the process parameters and input variables such as matrix type, filling material, and manufacturing method can reduce the erosive wear of the manufactured composites. Calcium carbonate $\left(\mathrm{CaCO}_{3}\right)$, barium sulphate $\left(\mathrm{BaSO}_{4}\right)$, and tungsten carbide (WC) filled glass fiber reinforced PA/ABS composite prepared by injection molding exhibited relatively lower erosive wear at higher impingement angle, i.e., $90^{\circ}$ or $75^{\circ}$ [40-42]. However, the incorporation of $\mathrm{CaCO}_{3}$ and $\mathrm{BaSO}_{4}$ promoted ductile and semi ductile erosive wear while WC promoted brittle wear of the composite. Treatment of fiber by chemical agents plays a crucial role in enhancing the resistance of composite against erosive wear. Benzoylated treated areca sheath fiber reinforced polyvinyl chloride exhibited lower erosive wear than untreated areca sheath fiber-reinforced composite [43]. In addition, fiber treatment encourages good bonding between fiber and matrix resulted in low erosive wear efficiency. The erosive wear of carbon and glass fibre reinforced composites demonstrated that they could attain excellent erosive wear resistance without using any ceramic filler; however, this was not the case with natural fibre reinforced composites. [44]. It is interesting to observe from the literature that synthetic fiber reinforced composites exhibited lower erosive wear than natural fiberreinforced polymer composite. Jute fiber has excellent strength, good UV protection, low thermal conduction and attractive anti-static properties which qualifies it a good reinforcing material. In addition, low cost Grewia optiva fiber, low density, easily available in the Himalayan region contains high amount of pectin (jelling and thickening agent) which is advantageous in making good bonding with polymeric chain and can be useful in a way of making cheaper and lighter prosthesis with good mechanical and tribological properties. As discussed in the literature, research on the erosive wear of composites combining both natural and synthetic fibers has been limited. As a result, the current research focuses on the hybridization of synthetic and natural fibres and compares the erosive wear of composites comprising three different resins: epoxy, polyester, and vinyl ester, using the Taguchi methodology as shown in the Figure 1.

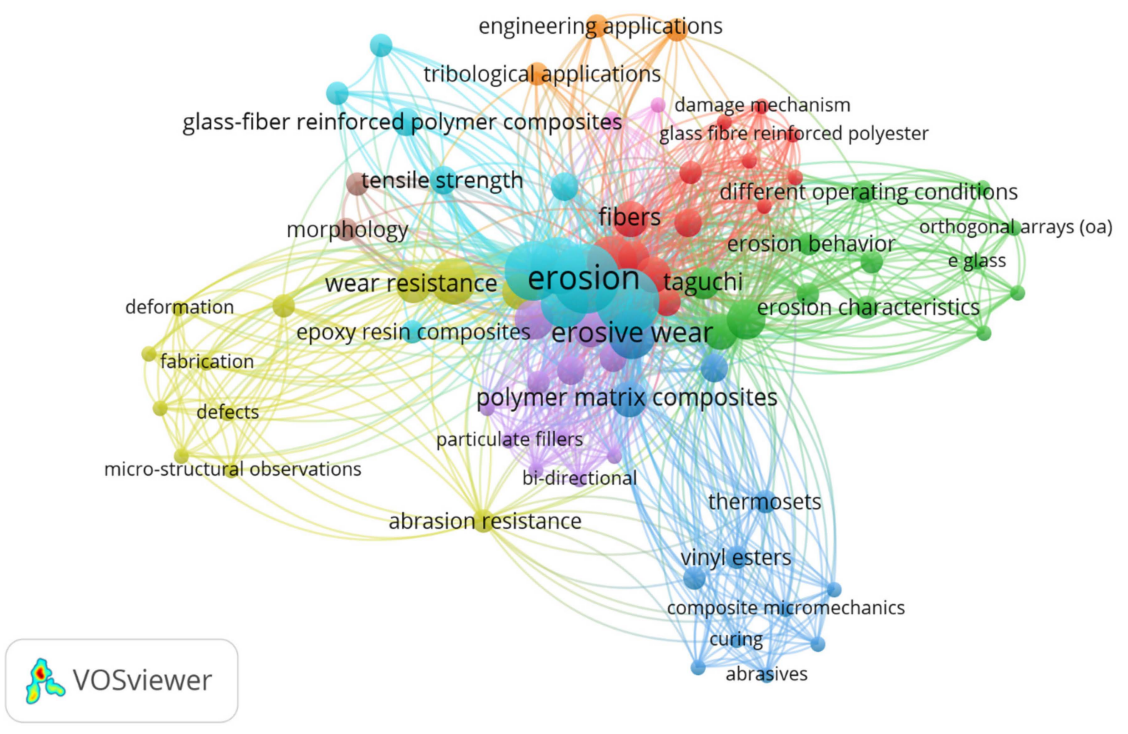

Figure 1. Bibliometrics visualisation overview of technology-based progressions on the erosionbehaviour of composites obtained from the various thermoset-resins (epoxy, polyester, and vinylester) for a multitude of scenarios. 


\section{Experimentation}

\subsection{Materials}

Bisphenol resin and epichlorohydrin were purchased from HEXION Specialty Chemicals Pvt. Ltd. Karnataka and mixed in the ratio of 5:1 for the preparation of epoxy (Epikote Resin 828), having good chemical resistance, internal adhesion, and appropriate wetting pigment. Esterification of epoxy with unsaturated mono carboxylic acid purchased from Amtech Ester Pvt. Ltd. Delhi was performed to prepare vinyl ester and dissolve the reactant in the solution of the solution styrene to provide stability to the prepared vinyl ester. Dibasic organic acids with polyhydric alcohols were purchased from Yes composites India Ltd. New Delhi and mixed in the appropriate ratio for the preparation of polyester.

Strand of chopped glass fiber having good strength and high insulating properties were procured from Yes composite Ltd. Natural fibers, i.e., jute and Grewia optiva were purchased in the form of bi-directional mat locally from the Uttarakhand Bamboo Board (India). These fibers were treated from $\mathrm{NaOH}$ solution with $8 \%$ concentration and then washed in distilled to remove dirt and dust present on the surface of fibers. Fibers used in the present investigation are shown in Figure 2.

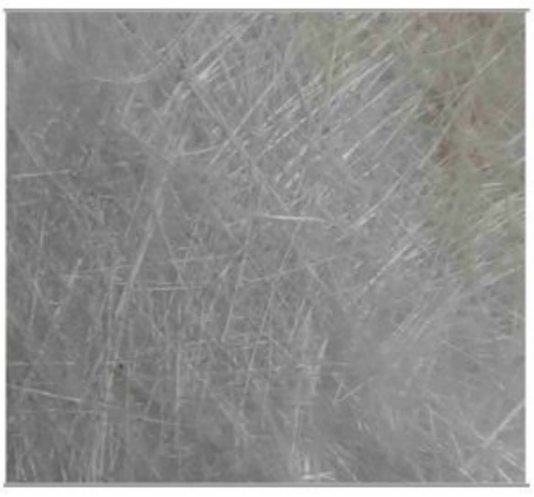

(a)

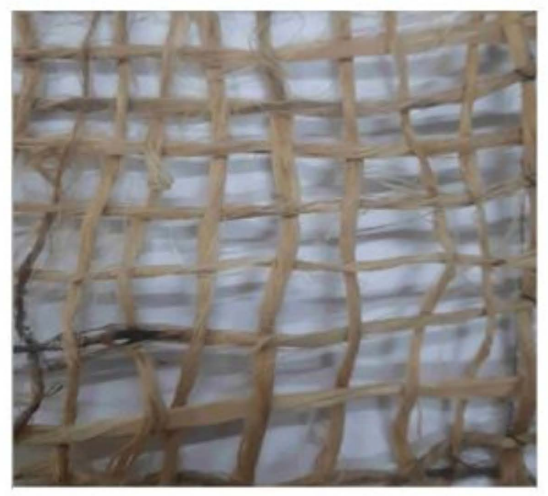

(b)

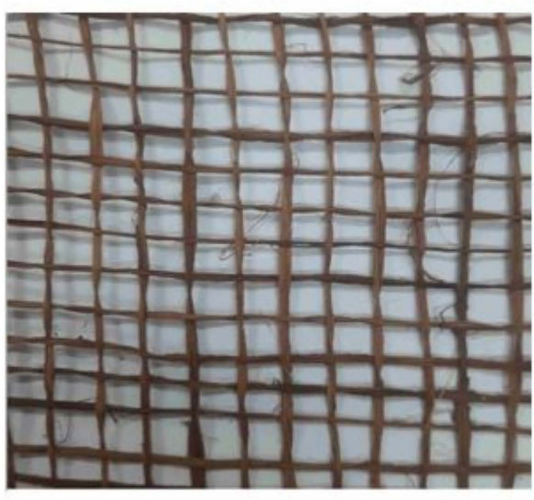

(c)

Figure 2. Showing (a) Glass fiber, (b) Jute fiber and (c) Grewia optiva fiber.

\subsection{Methods}

The composite samples were made using the hand lay-up approach, as shown in Figure 3. Glass plates measuring $500 \times 300 \times 4 \mathrm{~mm}^{3}$ were utilized as molding plates for composite manufacturing. Double-sided tape was used on all sides of the molding plate to achieve the desired thickness and secure the side bidding of the fabricated composite. Silicon spray was used over the molding plates to avoid the sticking of the sample with the plates. Firstly the resin was poured over the molding plates and evenly dispersed with the help of a steel roller, after which the natural and synthetic fibre mat of known percentage were placed one by one over the resin. Subsequently, the remaining resin was spread evenly over the mat with the help of a roller. Finally, a $15 \mathrm{~kg}$ load was held above the sample and left to cure. The composite sample was taken out of the mould and cut to the appropriate dimension for erosive wear characterization after $24 \mathrm{~h}$ of curing, as shown in Figure 4 . Samples fabricated by varying fiber weightage are illustrated in Table 1. 


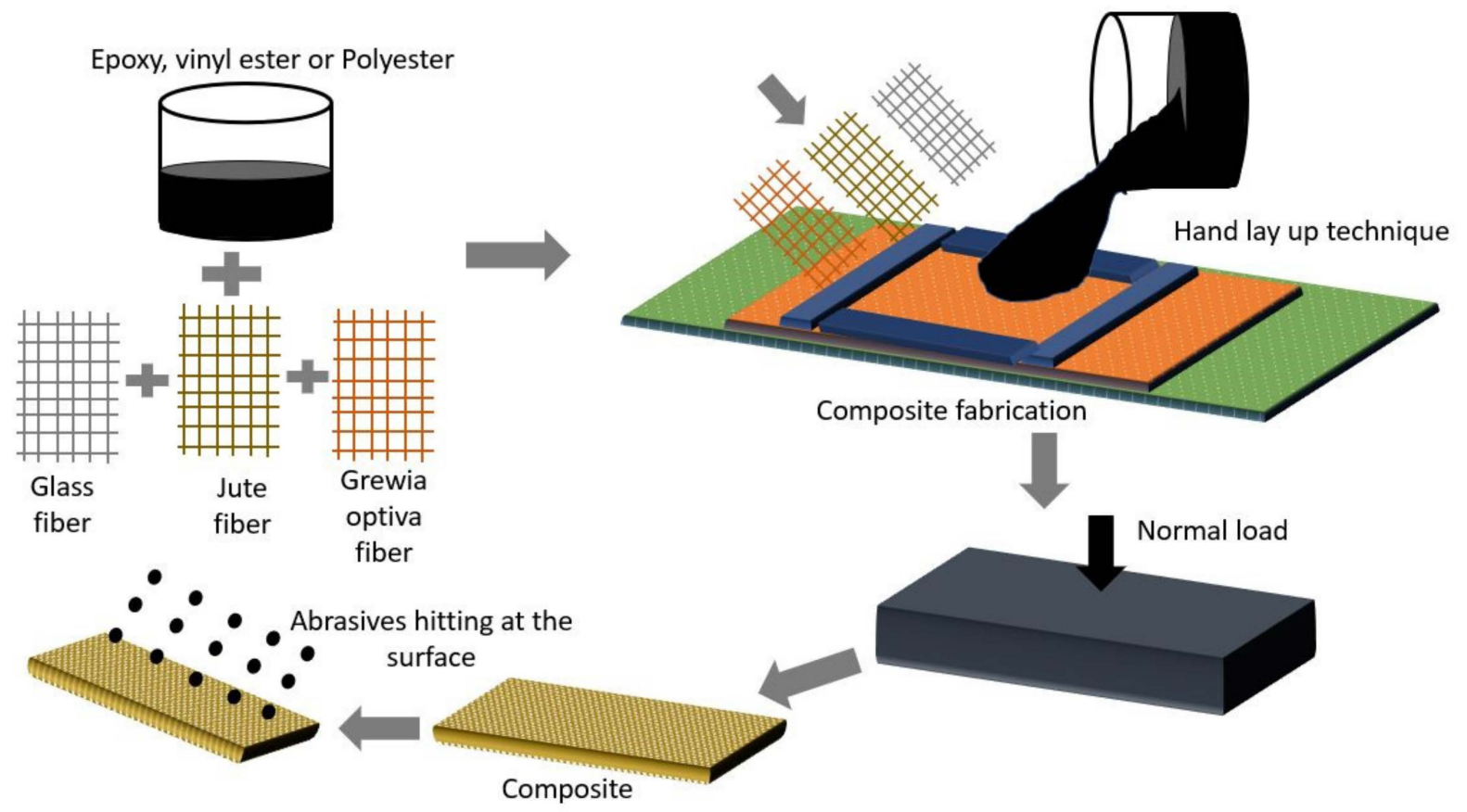

Figure 3. Process of fabrication of composite.

(a)

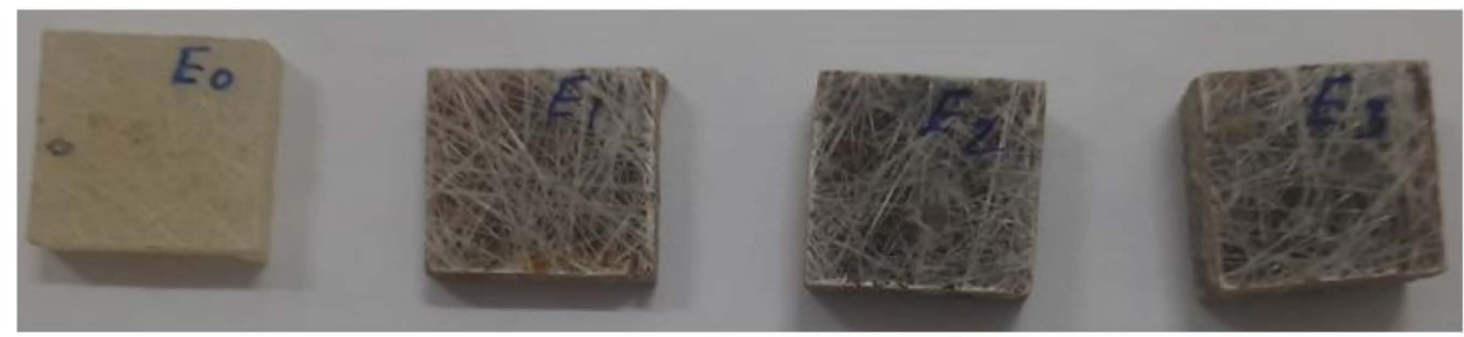

(b)

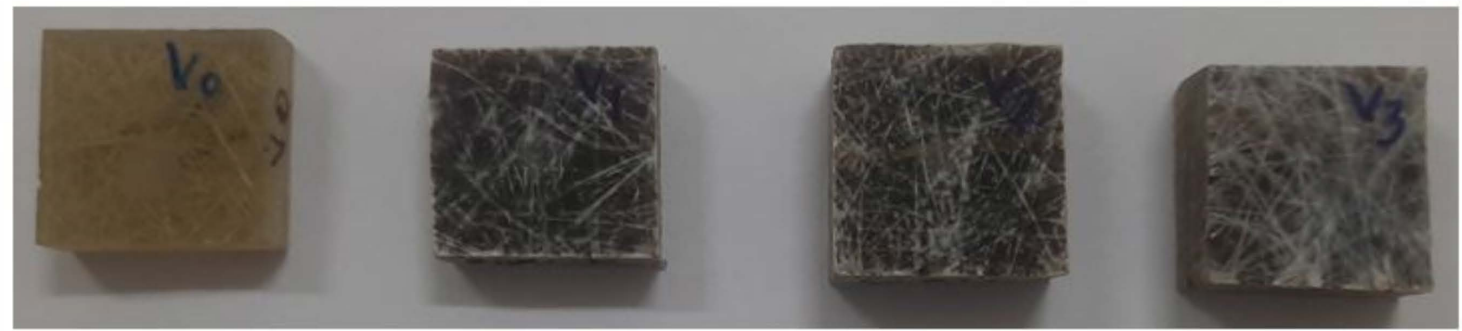

(c)

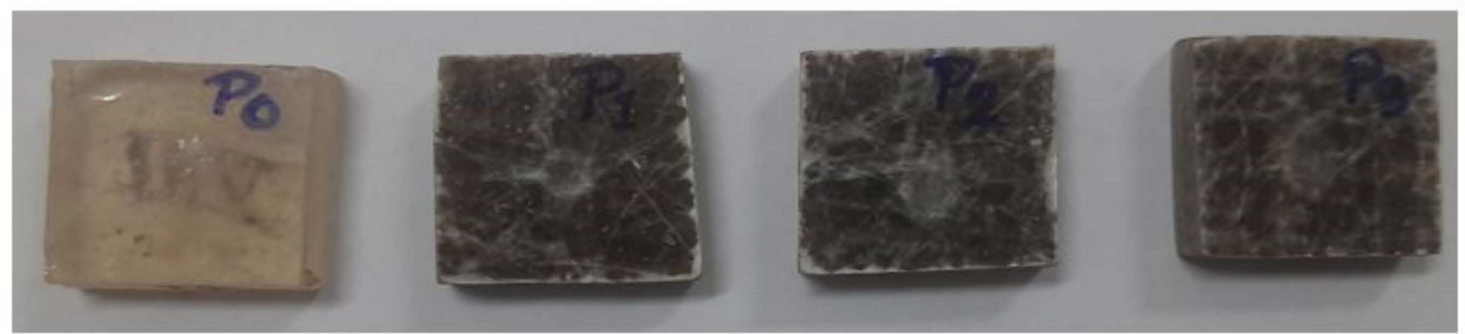

Figure 4. (a) Epoxy based, (b) vinyl ester based and (c) poly ester-based sample for erosive wear test. 
Table 1. Composition of fabricated composites.

\begin{tabular}{ccc}
\hline S. No. & Designation & Compositions \\
\hline 1 & E0 & Epoxy + Glass fiber $(5 \mathrm{wt} \%)$ \\
2 & E1 & Epoxy + glass fiber $(5 \mathrm{wt} \%)+$ jute $(2.5 \mathrm{wt} \%)+$ Grewia optiva $(2.5 \mathrm{wt} \%)$ \\
3 & $\mathrm{E} 2$ & Epoxy + glass fiber $(5 \mathrm{wt} \%)+$ jute $(5 \mathrm{wt} \%)+$ Grewia optiva $(5 \mathrm{wt} \%)$ \\
4 & $\mathrm{E} 3$ & Epoxy + glass fiber $(5 \mathrm{wt} \%)+$ jute $(7.5 \mathrm{wt} \%)+$ Grewia optiva $(7.5 \mathrm{wt} \%)$ \\
5 & $\mathrm{~V} 0$ & Vinyl ester + glass fiber $(5 \mathrm{wt} \%)$ \\
6 & $\mathrm{~V} 1$ & Vinyl ester + glass fiber $(5 \mathrm{wt} \%)+$ jute $(2.5 \mathrm{wt} \%)+$ Grewia optiva $(2.5 \mathrm{wt} \%)$ \\
7 & $\mathrm{~V} 2$ & Vinyl ester + glass fiber $(5 \mathrm{wt} \%)+$ jute $(5 \mathrm{wt} \%)+$ Grewia optiva $(5 \mathrm{wt} \%)$ \\
8 & $\mathrm{~V} 3$ & Vinyl ester + glass fiber $(5 \mathrm{wt} \%)+$ jute $(7.5 \mathrm{wt} \%)+$ Grewia optiva $(7.5 \mathrm{wt} \%)$ \\
9 & $\mathrm{P} 0$ & Polyester + glass fiber $(5 \mathrm{wt} \%)$ \\
10 & $\mathrm{P} 1$ & Polyester + glass fiber $(5 \mathrm{wt} \%)+$ jute $(2.5 \mathrm{wt} \%)+$ Grewia optiva $(2.5 \mathrm{wt} \%)$ \\
11 & $\mathrm{P} 2$ & Polyester + glass fiber $(5 \mathrm{wt} \%)+$ jute $(5 \mathrm{wt} \%)+$ Grewia optiva $(5 \mathrm{wt} \%)$ \\
12 & $\mathrm{P3}$ & Polyester + glass fiber $(5 \mathrm{wt} \%)+$ jute $(7.5 \mathrm{wt} \%)+$ Grewia optiva $(7.5 \mathrm{wt} \%)$ \\
\hline
\end{tabular}

\subsection{Erosive Wear Analysis}

The analysis of erosive wear for the fabricated samples was carried out as per ASTM-G 76 standard of size $30 \times 30 \times 5 \mathrm{~mm}^{3}$ on air jet erosion tester supplied by DUCOM, India as shown in Figure 5. The erodent particles used in the experiment were silica of size varying from 100 to $250 \mu \mathrm{m}$. Silica particles were forced to impinge at the surface of the sample through a tungsten carbide nozzle for $15 \mathrm{~min}$ at different experimental conditions. After completing the test, the surface of the samples was cleaned by using acetone, and an electronic weighing machine measured its weight.

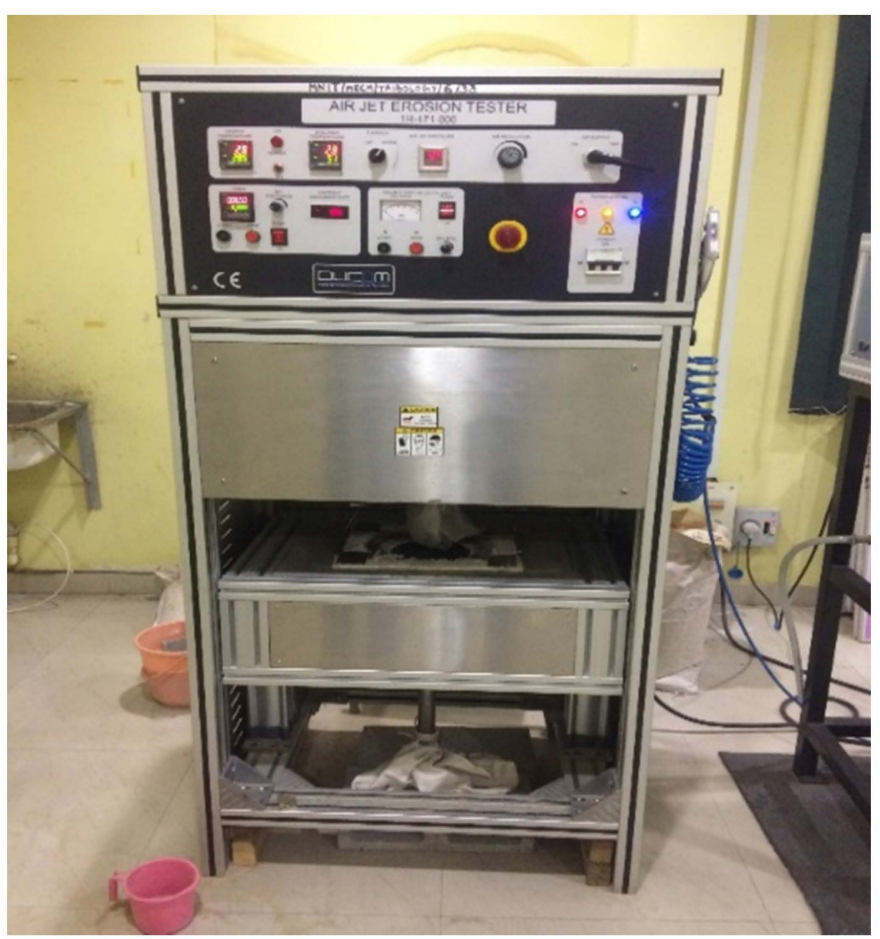

Figure 5. Air jet erosion test machine set up.

\subsection{Taguchi Experiment Design}

Various control factors influence the erosive wear, such as the size of the erosive particle, velocity of impact, angle of impingement, filler content, concentration, etc. In this present investigation, erosive wear is assessed by evaluating three control factors, each having four levels as tabulated in Table 2. 
Table 2. Control factors and respective levels.

\begin{tabular}{cccccc}
\hline Control Factors & \multicolumn{5}{c}{ Levels } \\
\cline { 2 - 6 } & I & II & III & IV & Units \\
\hline Impact Velocity & 30 & 40 & 50 & 60 & $\mathrm{~m} / \mathrm{s}$ \\
Impingement angle & 45 & 60 & 75 & 90 & degree \\
Fiber content & & & & \\
(For composites $\left.\mathrm{E}_{1}, \mathrm{E}_{2}, \mathrm{E}_{3}\right)$ & 0 & 05 & 10 & 15 & $\mathrm{wt} \%$ \\
(For composites $\left.\mathrm{V}_{1}, \mathrm{~V}_{2}, \mathrm{~V}_{3}\right)$ & 0 & 05 & 10 & 15 & \\
(For composites $\left.\mathrm{P}_{1}, \mathrm{P}_{2}, \mathrm{P}_{3}\right)$ & 0 & 05 & 10 & 15 & \\
\hline
\end{tabular}

Considering Table 2, if all the experiments are to be performed, it will be 81 numbers for three control factors and four levels. It will become cumbersome and laborious. Moreover, a lot of time and energy will be required, which makes it a costly deal. Alternatively, the Taguchi approach can be applied, which uses an orthogonal array to break down the 81 numbers in just a handful of experiments offering enough control factors as provided by 81 experiments. Here, $\mathrm{L}_{16}$ orthogonal array has been constructed as shown in Table 3 for the investigation in the Minitab to analyse erosive wear. Moreover, signal to noise (S/N) ratio was analysed using lower the better characteristics as per equation 1to examine the erosive wear of the composite samples.

Table 3. Design-matrix array arrangement.

\begin{tabular}{cccc}
\hline S. No. & Impact Velocity $(\mathbf{m} / \mathbf{s})$ & Natural Fiber $(\mathbf{w t} \%)$ & $\begin{array}{c}\text { Impingent Angle } \\
\text { (Degree) }\end{array}$ \\
\hline 1 & 30 & 0 & 45 \\
2 & 30 & 5 & 60 \\
3 & 30 & 10 & 75 \\
4 & 30 & 15 & 90 \\
5 & 40 & 0 & 60 \\
6 & 40 & 5 & 45 \\
7 & 40 & 10 & 90 \\
8 & 40 & 15 & 75 \\
9 & 50 & 0 & 75 \\
10 & 50 & 5 & 90 \\
11 & 50 & 10 & 45 \\
12 & 50 & 15 & 60 \\
13 & 60 & 0 & 90 \\
14 & 60 & 5 & 75 \\
15 & 60 & 10 & 60 \\
16 & 60 & 15 & 45 \\
\hline
\end{tabular}

Lower-the-better characteristic:

$$
\mathrm{S} / \mathrm{N} \text { ratio }=-10 \log \frac{1}{n}\left(\sum_{i=1}^{n} \mathrm{y}_{i}\right)
$$

Here, $\mathrm{y}$ is erosive wear and $n$ is number of experiments.

Literature-Based on Erosive Wear Analysis of Polymer Composites Using Taguchi Approach

The erosive wear analysis of fiber/filler reinforced polymer composites has been carried out recently at different impact velocities, filler content, impingement angle, erodent size, etc., as shown in Table 4. Several types of orthogonal array have been used to examine the effect of different control factors on the erosive wear of composite. Table 4 suggests that erosive wear gets significantly affected by altering the controlling factors. Initially, orthogonal arrays were used only for composite containing epoxy or polyester based composites. But limited or none of the studies were done on vinyl ester-based composites. 
Furthermore, the effect of three fibers in a composite with different resins has rarely been investigated.

Table 4. List of work carried out for erosive wear using Taguchi experiment.

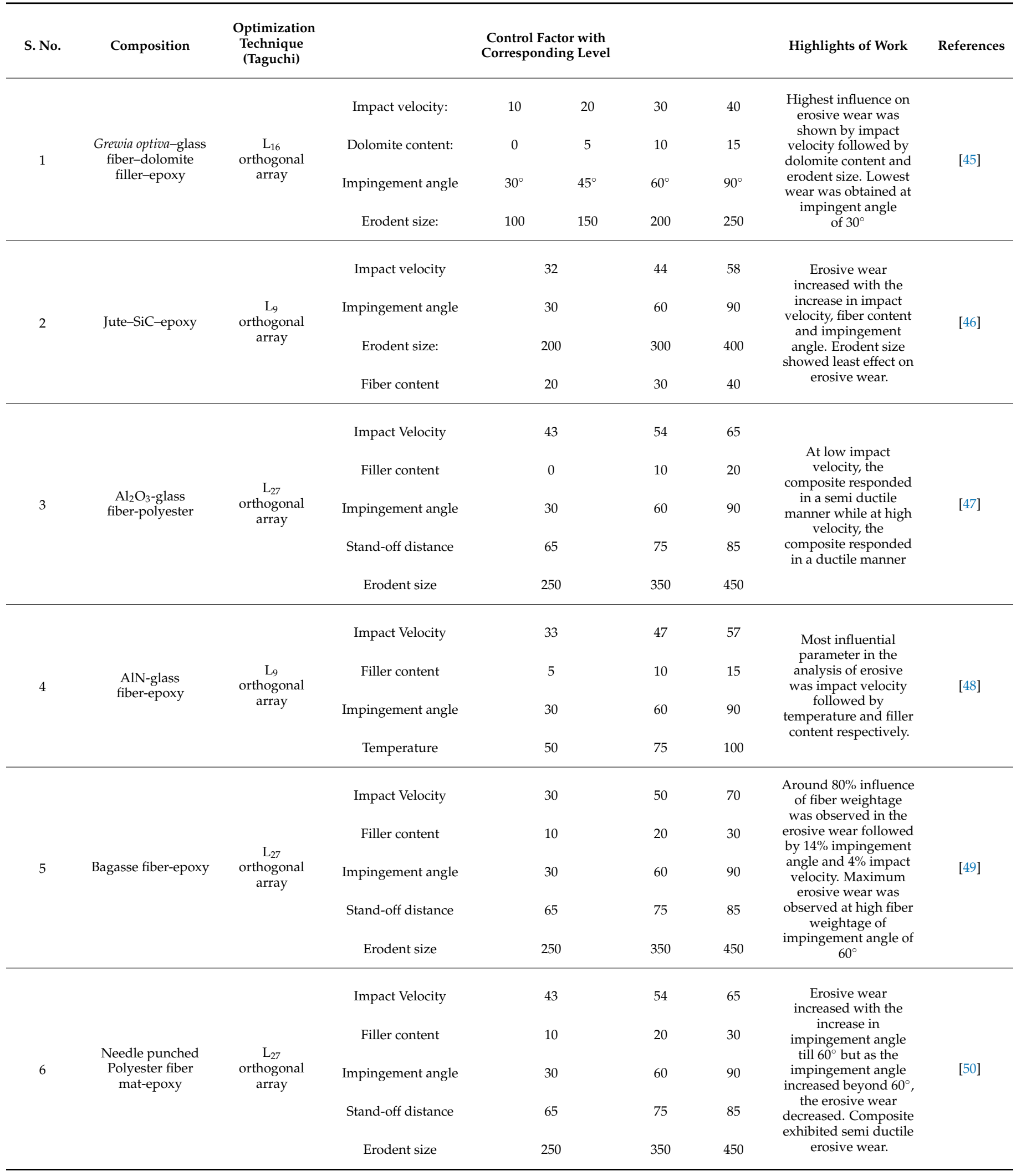


Table 4. Cont.

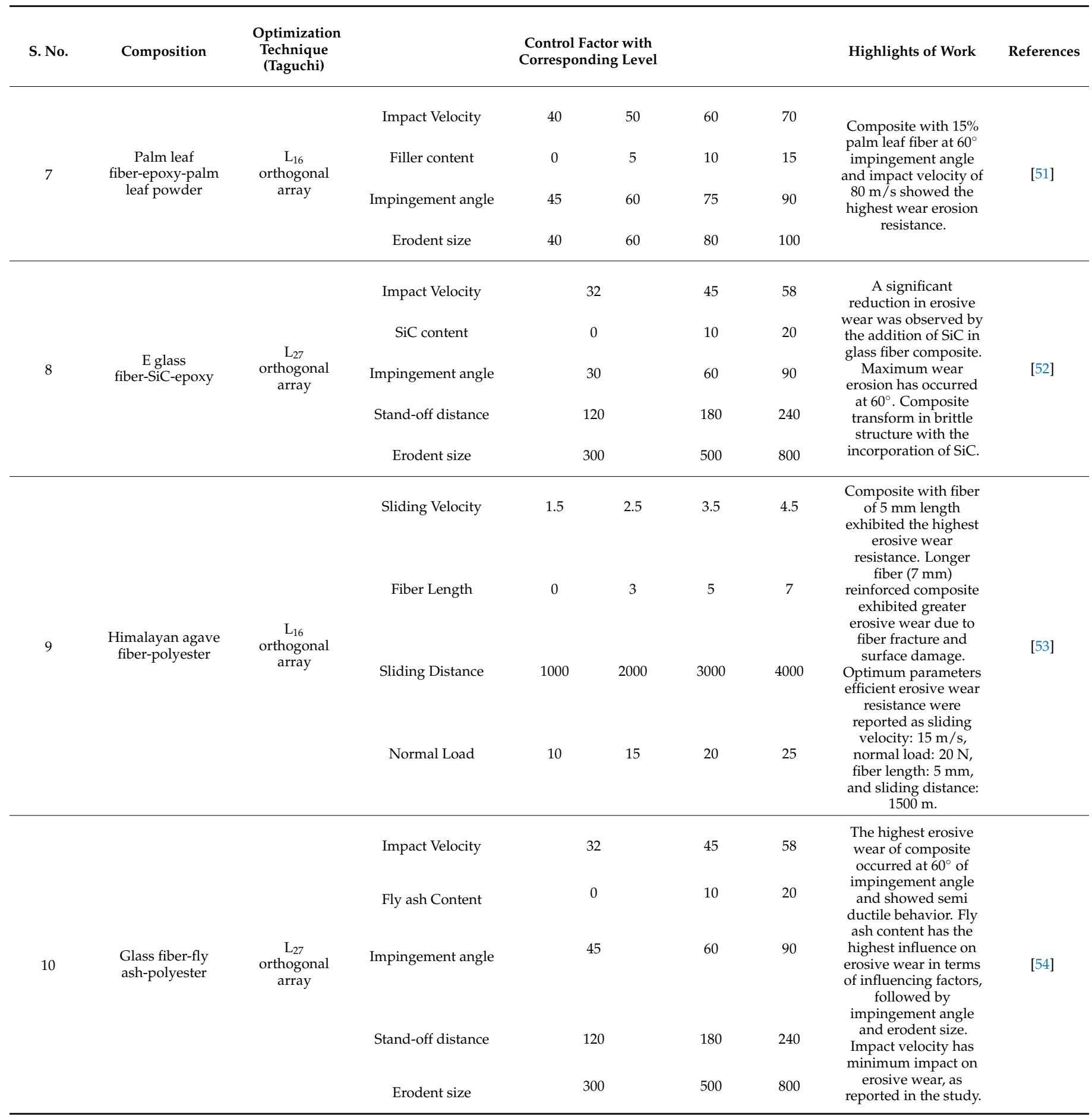

Note: Impact velocity: $(\mathrm{m} / \mathrm{s})$, erodent size: $(\mathrm{mm})$, impingement angle: (degree), stand-off distance: $(\mathrm{mm})$, normal load: $(\mathrm{N})$, sliding distance: $(\mathrm{m})$, fiber/filler content: (weight percentage), fiber length: (mm).

\section{Results and Discussions}

\subsection{Mechanical Properties}

The properties shown in Table 5 are the average of 3 readings taken for each sample which has taken from previous research [55]. When the tensile strength of composites was compared, it was discovered that epoxy-based composites had the maximum tensile strength, $72 \mathrm{MPa}$, at $15 \mathrm{wt} \%$ loading of jute and Grewia optiva fibre. However, in the case of flexural strength, the vinyl ester based composites outperformed both epoxy and polyester- 
based composites with the highest value of $48 \mathrm{MPa}$ at $5 \mathrm{wt} \%$ loading of both jute and Grewia optiva fiber. The impact and hardness values were found to be higher for epoxy-based composites. The properties depicted in the Table 5 shows that the fiber reinforcement in epoxy is more advantageous than reinforcement in vinyl ester and polyester due to higher overall enhancement of mechanical properties. The reduction of the mechanical property in viny ester and polyester composites can be related to the photochemical degradation, plasticizing effect, and weak interfacial adhesion, weakening the interface between the matrix and fillers. On the other hand, epoxy-based composites accomplish efficient mechanical interlocking between the fibre and epoxy, resulting in good stress transfer from the epoxy to the fiber $[56,57]$.

Table 5. Mechanical properties of composites.

\begin{tabular}{ccccc}
\hline & \multicolumn{4}{c}{ Mechanical Properties } \\
\cline { 2 - 5 } Sample & $\begin{array}{c}\text { Tensile Strength } \\
\text { (MPa) }\end{array}$ & $\begin{array}{c}\text { Flexural Strength } \\
\text { (MPa) }\end{array}$ & $\begin{array}{c}\text { Impact } \\
\text { Strength (J) }\end{array}$ & $\begin{array}{c}\text { Hardness } \\
\text { (HRL) }\end{array}$ \\
\hline E0 & 38 & 22 & 1.2 & 52 \\
E1 & 54 & 38 & 1.4 & 68 \\
E2 & 68 & 42 & 1.68 & 76 \\
E3 & 72 & 36 & 2.1 & 57 \\
V0 & 32 & 24 & 1.1 & 38 \\
V1 & 47 & 42 & 1.2 & 48 \\
V2 & 62 & 48 & 1.5 & 54 \\
V3 & 69 & 38 & 1.9 & 42 \\
P0 & 28 & 18 & 0.9 & 44 \\
P1 & 42 & 28 & 1.05 & 56 \\
P2 & 56 & 35 & 1.26 & 64 \\
P3 & 60 & 31 & 1.71 & 51 \\
\hline
\end{tabular}

\subsection{Taguchi Analysis of Erosive Wear}

On the prepared composites, three control factors and four levels were investigated using the $\mathrm{L}_{16}$ orthogonal array. The analysis of several combinations of control factors was performed using Minitab 15. Erosive wear rates of different resin-based composite and their corresponding $\mathrm{S} / \mathrm{N}$ ratio have been presented in Table 6 . Furthermore, the effect of control factor on the erosive wear with the respective ranking is tabulated in Table 6 . Observations revealed that the control factor which influenced erosive the most was found to be impact velocity. The effect of fiber content on erosive wear was low as compared to impact velocity but quite considerable. Impingement angle has the least effect on erosive wear among all the three control factors. Further, a graph of control factors at different levels is shown in Figure 4. For epoxy-based composites, it can be concluded from Table 6 that erosive wear increases with the increase in impact velocity and is found to be minimum at an Impact velocity of $30 \mathrm{~m} / \mathrm{s}, 15 \mathrm{wt} \%$ fiber reinforcement and impingement angle of $90^{\circ}$ whereas maximum erosive wear was obtained at $60 \mathrm{~m} / \mathrm{s} 0 \mathrm{wt} \%$ fiber reinforcement and impingement angle of $90^{\circ}$. This indicates that the addition of fiber in epoxy does not necessarily influence the erosive wear but also the impingement angle. When the erodent particles hit the composite surface, the epoxy material is first contacted and then the reinforcement after the erosion. The Rockwell hardness of epoxy is relatively high, with an outstanding value of 80 number, which is capable of bearing the impact of erodent particle at such high velocity. The respective $\mathrm{S} / \mathrm{N}$ ratio at $3 \mathrm{rd}$ run and 13th run erosive wear is also the evidence for minimum and maximum erosive wear. 
Table 6. Erosive wear and corresponding $\mathrm{S} / \mathrm{N}$ ratio of the composites.

\begin{tabular}{|c|c|c|c|c|c|c|}
\hline S. No. & $\begin{array}{c}\text { Erosive Wear of } \\
\text { Epoxy } \\
(\mathrm{mg} / \mathrm{kg})\end{array}$ & S/N Ratios & $\begin{array}{l}\text { Erosive Wear of } \\
\text { Vinyl Ester } \\
(\mathrm{mg} / \mathrm{kg})\end{array}$ & S/N Ratios & $\begin{array}{c}\text { Erosive Wear of } \\
\text { Polyester } \\
\text { (mg/kg) }\end{array}$ & S/N Ratios \\
\hline 1 & 298.96 & -49.5123 & 304.67 & -49.6766 & 309.88 & -49.8239 \\
\hline 2 & 218.47 & -46.7878 & 221.08 & -46.8910 & 232.10 & -47.3135 \\
\hline 3 & 219.06 & -46.8113 & 236.11 & -47.4623 & 228.07 & -47.1614 \\
\hline 4 & 209.65 & -46.4299 & 305.44 & -49.6985 & 253.45 & -48.0778 \\
\hline 5 & 338.75 & -50.5976 & 445.21 & -52.9713 & 318.85 & -50.0717 \\
\hline 6 & 260.37 & -48.3118 & 278.021 & -48.8816 & 297.92 & -49.4820 \\
\hline 7 & 309.44 & -49.8115 & 211.67 & -46.5132 & 247.81 & -47.8824 \\
\hline 8 & 311.23 & -49.8616 & 309.37 & -49.8096 & 384.53 & -51.6986 \\
\hline 9 & 461.64 & -53.2861 & 361.09 & -51.1523 & 506.43 & -54.0904 \\
\hline 10 & 416.86 & -52.3998 & 398.56 & -52.0099 & 434.67 & -52.7632 \\
\hline 11 & 306.99 & -49.7425 & 380.88 & -51.6158 & 371.09 & -51.3896 \\
\hline 12 & 386.25 & -51.7374 & 432.01 & -52.7099 & 489.56 & -53.7961 \\
\hline 13 & 527.65 & -54.4469 & 550.84 & -54.8205 & 588.19 & -55.3904 \\
\hline 14 & 520.97 & -54.3363 & 554.41 & -54.8766 & 566.71 & -55.0672 \\
\hline 15 & 364.06 & -51.2235 & 381.56 & -51.6313 & 408.34 & -52.2204 \\
\hline 16 & 411.85 & -52.2948 & 415.51 & -52.3716 & 421.01 & -52.4858 \\
\hline
\end{tabular}

It can also be observed from Table 6 that the erosive wear of vinyl ester composites among the 16 runs was found to be minimum at 7 th run maximum at 14th run, which is at an impact velocity of $40 \mathrm{~m} / \mathrm{s}$, fiber weightage of $10 \mathrm{wt} \%, 90^{\circ}$ impingement angle and impact velocity of $60 \mathrm{~m} / \mathrm{s}$, fiber weightage of $0 \mathrm{wt} \%$, impingement angle of $75^{\circ}$. The magnitude of erosive wear was approximately similar to epoxy-based composites but $0.7 \%$ higher in magnitude. Interestingly, the most increased erosive wear occurs at $75^{\circ}$ impingement angle and $0 \mathrm{wt} \%$. This shows that fiber inclusion in the vinyl ester composites reduces the erosive wear, and impingement angles from $75^{\circ}$ to $90^{\circ}$ showed the same erosive wear. Moreover, the upsurge in impact velocity increases the erosive wear of the vinyl ester composite.

Erosive wear for polyester-based composites was found to be higher as compared to both epoxy and vinyl ester-based composites. It was observed that minimum and maximum erosive wear were obtained at an impact velocity of $30 \mathrm{~m} / \mathrm{s}$, fiber reinforcement of $0 \mathrm{wt} \%, 75^{\circ}$ impingement angle (3rd run) and impact velocity of $60 \mathrm{~m} / \mathrm{s}$, fiber reinforcement of $0 \mathrm{wt} \%$ and impingement angle of $90^{\circ}$ (13th run), respectively. The reason of higher wear may be attributed to the low hardness of polyester resulting in low resistance against the impact of erodent particles [58].

The analysis of results as shown in Figure 6 concludes that the combination at an impact velocity of $30 \mathrm{~m} / \mathrm{s}$, fiber content of $10 \mathrm{wt} \%$ and impingement angles of $45^{\circ}$ yields the lowest erosive wear in epoxy-based composites. For the vinyl ester composites, the lowest wear rate was obtained for the combination at impact velocity of $30 \mathrm{~m} / \mathrm{s}$ and fiber content of $10 \mathrm{wt} \%$ and impingement angles of $45^{\circ}$. Additionally, in the case of polyester-based composite, the lowest erosive wear was obtained at $30 \mathrm{~m} / \mathrm{s}$, fiber content of $10 \mathrm{wt} \%$ and impingement angles of $45^{\circ}$. Furthermore, as described in Table 7 , the order of effectiveness of control factors is impact velocity (1st), fiber content (2nd), and impingement angle (3rd). 

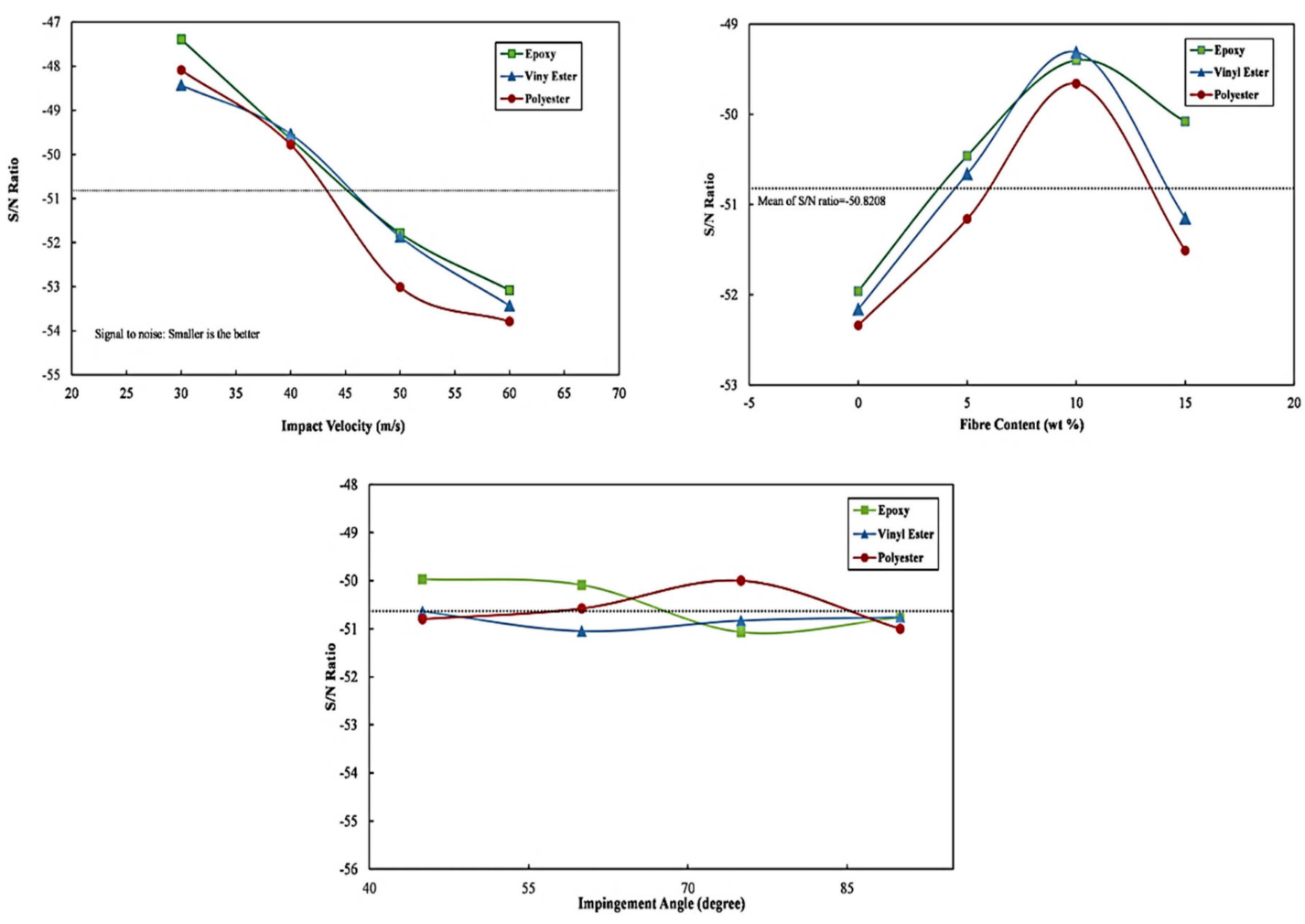

Figure 6. Mean of S/N ratio for epoxy (ep), vinyl ester (ve) and polyester (pe) based composites.

Table 7. Response table for composites.

\begin{tabular}{|c|c|c|c|c|c|c|c|c|c|}
\hline \multirow[b]{2}{*}{ Levels } & \multicolumn{3}{|c|}{ Epoxy } & \multicolumn{3}{|c|}{ Vinyl Ester } & \multicolumn{3}{|c|}{ Polyester } \\
\hline & $\begin{array}{c}\text { Impact } \\
\text { Velocity } \\
(\mathrm{m} / \mathrm{s})\end{array}$ & $\begin{array}{c}\text { Fiber } \\
\text { Content } \\
(w t \%)\end{array}$ & $\begin{array}{c}\text { Impingement } \\
\text { Angle } \\
\text { (Degree) }\end{array}$ & $\begin{array}{c}\text { Impact } \\
\text { Velocity } \\
(\mathrm{m} / \mathrm{s})\end{array}$ & $\begin{array}{c}\text { Fiber } \\
\text { Content } \\
(w t \%)\end{array}$ & $\begin{array}{c}\text { Impingement } \\
\text { Angle } \\
\text { (Degree) }\end{array}$ & $\begin{array}{c}\text { Impact } \\
\text { Velocity } \\
(\mathrm{m} / \mathrm{s})\end{array}$ & $\begin{array}{l}\text { Fiber } \\
\text { Content } \\
(w t \%)\end{array}$ & $\begin{array}{c}\text { Impingement } \\
\text { Angle } \\
\text { (Degree) }\end{array}$ \\
\hline 1 & -47.39 & -51.96 & -49.97 & -48.43 & -52.16 & -50.64 & -48.09 & -52.34 & -50.8 \\
\hline 2 & -49.65 & -50.46 & -50.09 & -49.54 & -50.66 & -51.05 & -49.78 & -51.16 & -50.58 \\
\hline 3 & -51.79 & -49.40 & -51.07 & -51.87 & -49.31 & -50.83 & -53.01 & -49.66 & -50 \\
\hline 4 & -53.08 & -50.08 & -50.77 & -53.43 & -51.15 & -50.76 & -53.79 & -51.51 & -51 \\
\hline Delta & 5.69 & 2.56 & 1.11 & 4.99 & 2.85 & 0.41 & 5.7 & 2.68 & 1.21 \\
\hline Rank & 1 & 2 & 3 & 1 & 2 & 3 & 1 & 2 & 3 \\
\hline
\end{tabular}

\section{Analysis of Variance}

Analysis of variance (ANOVA) was used for the analysis of the statistical significance of control factors at $95 \%$ confidence level. The $p$-value of control factors or epoxy-based composites is shown in Table 8 which shows the degree of significance of the control factor on erosive wear. It was observed that the value of $p$ for impact velocity is 0.001 which is lower than assumed $p$-value, i.e., 0.05 and is the most significant factor for the analysis of erosive wear. The next significant factor was fiber content with the $p$-value of 0.046 . Impingement angle was observed to be least significant factor as per the ANOVA Table 8. The contribution of all the factors for epoxy-based composites with the highest contribution of impact velocity has a value of $76.35 \%$, followed by fiber content with the contribution factor of $14.36 \%$ and the least contribution of impingement angle with $3.49 \%$ is shown in Figure 7. 
Table 8. Analysis of variance for SNRA2, using adjusted SS for tests epoxy-based composites.

\begin{tabular}{ccccccc}
\hline Source & DF & Seq SS & Adj SS & Adj MS & F-Value & $p$-Value \\
\hline Impact Velocity $(\mathrm{m} / \mathrm{s})$ & 3 & 74.915 & 74.915 & 24.972 & 26.43 & 0.001 \\
Fiber content $(\mathrm{wt} \%)$ & 3 & 14.098 & 14.098 & 4.699 & 4.97 & 0.046 \\
Impingement angle & 3 & 3.43 & 3.43 & 1.143 & 1.21 & 0.384 \\
$\quad$ (Degree) & 6 & 5.67 & 5.67 & 0.945 & & \\
$\quad$ Error & 15 & 98.113 & & & & \\
Total & & &
\end{tabular}

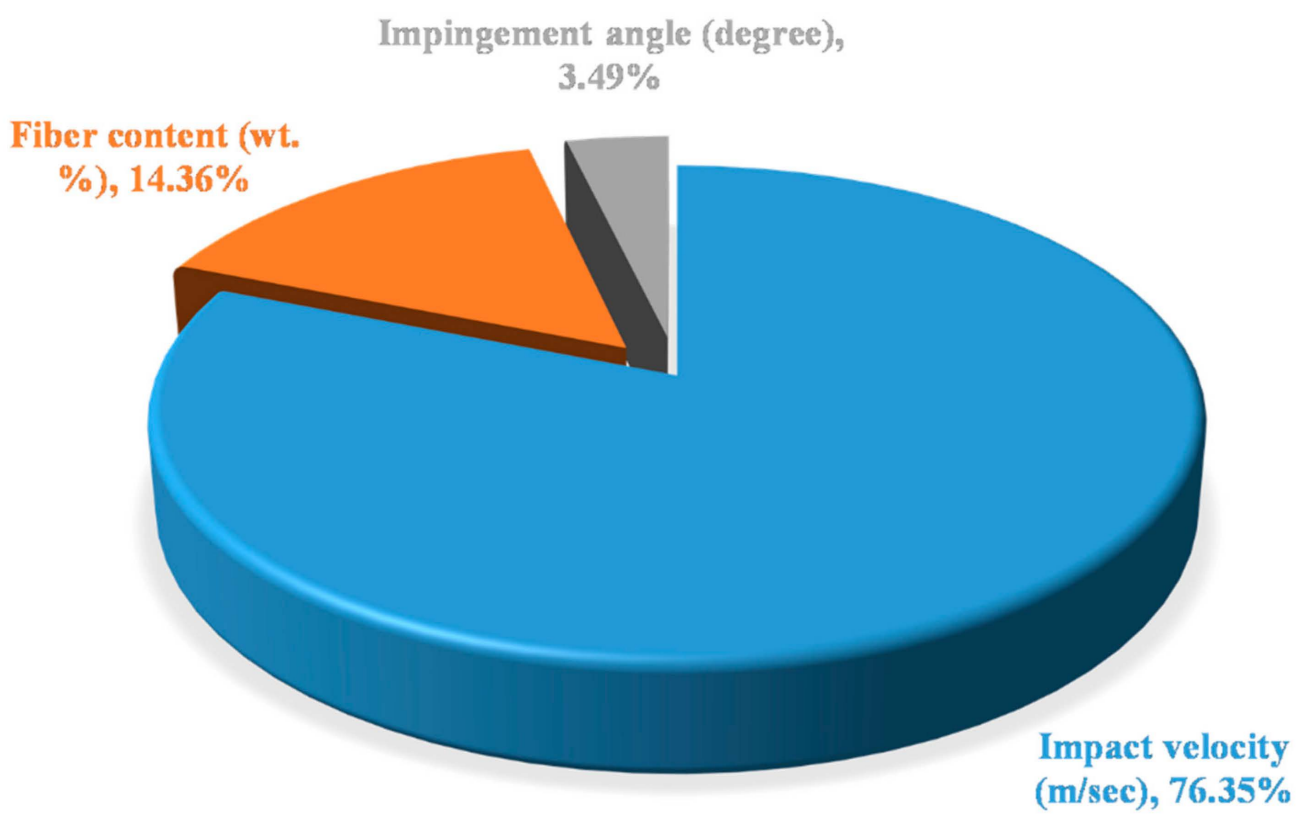

Figure 7. Contribution chart of factors for epoxy-based composites.

The $p$-value of control factors or vinyl ester-based composites is shown in Table 9. It was observed that the value of $p$ for impact velocity is 0.0031 , which is lower than the assumed $p$-value, i.e., 0.05 , and is the most significant factor for the analysis of erosive wear. The next significant factor was fiber content with the $p$-value of 0.275 . Impingement angle was observed to be the least significant factor as per the ANOVA Table 9. The contribution of all the factors for vinyl ester-based composites with the highest contribution of impact velocity has a value of $61.82 \%$, followed by fiber content with the contribution factor of $17.15 \%$ and the least contribution of impingement angle with $0.37 \%$ is shown in Figure 8.

Table 9. Analysis of Variance for SNRA2, using adjusted SS for tests vinylester based composites.

\begin{tabular}{ccccccc}
\hline Source & DF & Seq SS & Adj SS & Adj MS & F-Value & $p$-Value \\
\hline Impactvelocity (m/s) & 3 & 60.893 & 60.893 & 20.298 & 5.97 & 0.031 \\
Fiber content (wt\%) & 3 & 16.829 & 16.829 & 5.61 & 1.65 & 0.275 \\
Impingement angle & 3 & 0.362 & 0.362 & 0.121 & 0.04 & 0.99 \\
(Degree) & 6 & 20.405 & 20.405 & 3.401 & & \\
Error & 15 & 98.489 & & & & \\
Total & &
\end{tabular}




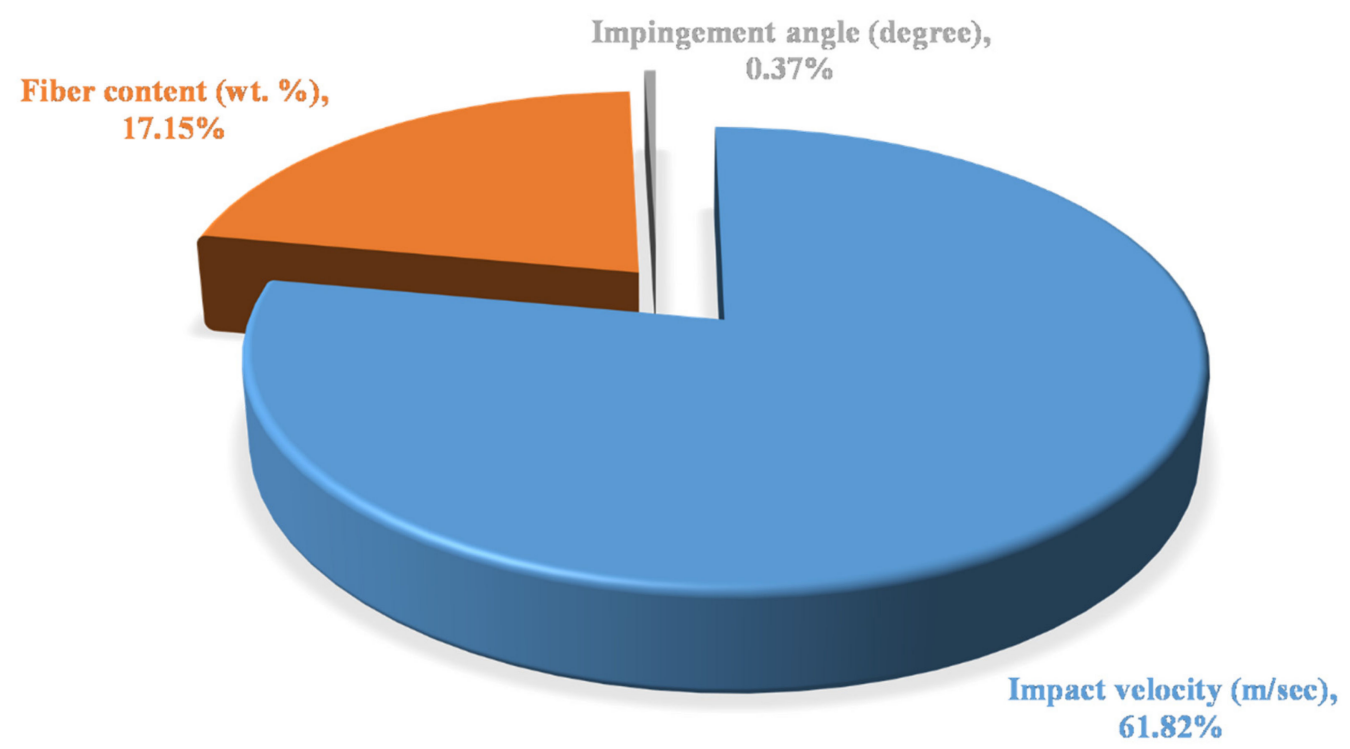

Figure 8. Contribution chart of factors for vinyl ester-based composites.

The $p$-value of control factors or polyester-based composites is shown in Table 10. It was observed that the value of $p$ for impact velocity is 0.001 , which is lower than the assumed $p$-value, i.e., 0.05 , and is the most significant factor for the analysis of erosive wear. The next significant factor was fiber content with a $p$-value of 0.043. Impingement angle was observed to be least significant factor as per the ANOVA Table 10. The contribution of all the factors for epoxy-based composites with the highest contribution of impact velocity has a value of $77.75 \%$, followed by fiber content with the contribution factor of $13.53 \%$ and least contribution of impingement angle with $3.44 \%$ is shown in Figure 9.

Table 10. Analysis of variance for SNRA2, using adjusted SS for tests polyester.

\begin{tabular}{ccccccc}
\hline Source & DF & Seq SS & Adj SS & Adj MS & F-Value & $p$-Value \\
\hline Impact Velocity (m/s) & 3 & 86.549 & 86.549 & 28.85 & 29.58 & 0.001 \\
Fiber content (wt\%) & 3 & 15.069 & 15.069 & 5.023 & 5.15 & 0.043 \\
Impingement angle & 3 & 3.835 & 3.835 & 1.278 & 1.31 & 0.355 \\
$\quad$ (Degree) & 6 & 5.853 & 5.853 & 0.975 & & \\
Error & 15 & 111.305 & & & & \\
Total & &
\end{tabular}

\subsection{Morphological Analysis}

The Figure 10 illustrates the mechanism took place during the wear examination of all three types of composites at highest fiber loading. Epoxy based composites as shown in Figure 10a exhibited fiber pull out leading to exposure of fibers with the wear surface [56-62]. The patches of ploughing at macro level have also been observed which may be considered as the major factor in the wear of the composite. However, the overall wear of epoxy-based composites reduced by the interaction of fiber with the mating surface took place by fiber pull out. It is to be noted that addition of jute and grewia fibers in the glass fiber-epoxy composites increases the erosive wear till $10 \mathrm{wt} \%$ of loading. However, on increasing the natural fiber weightage beyond 10\% loading, the erosive wear behaviour reduces significantly. Large wear debris was spotted in vinyl ester-based composites (Figure 10b). These wear debris formed due to the detachment of sub polymeric material from base material due to low van der wall forces. Here, the exposure of fiber is negligible which somehow can be linked to the comparative higher wear than epoxy-based composites. In case of polyester composites (Figure 10c). The bonding between the natural fiber and ester group of vinyl ester and polyester matrix is comparatively low as compared to epoxy-natural fiber bonding which triggered more fiber detachment. Interestingly, at 
higher natural fiber loading ( $15 \mathrm{wt} \%$ jute and grewia), the improvement in the erosive wear was not significant as obtained in the study. Apparently, the erosive wear examination revealed that main wear mechanism responsible for material removal is groove formation and micro-ploughing [63-65]. A close examination also discloses brittle fractures at some parts, which shows that a small amount of impact forces was also acting on the samples.

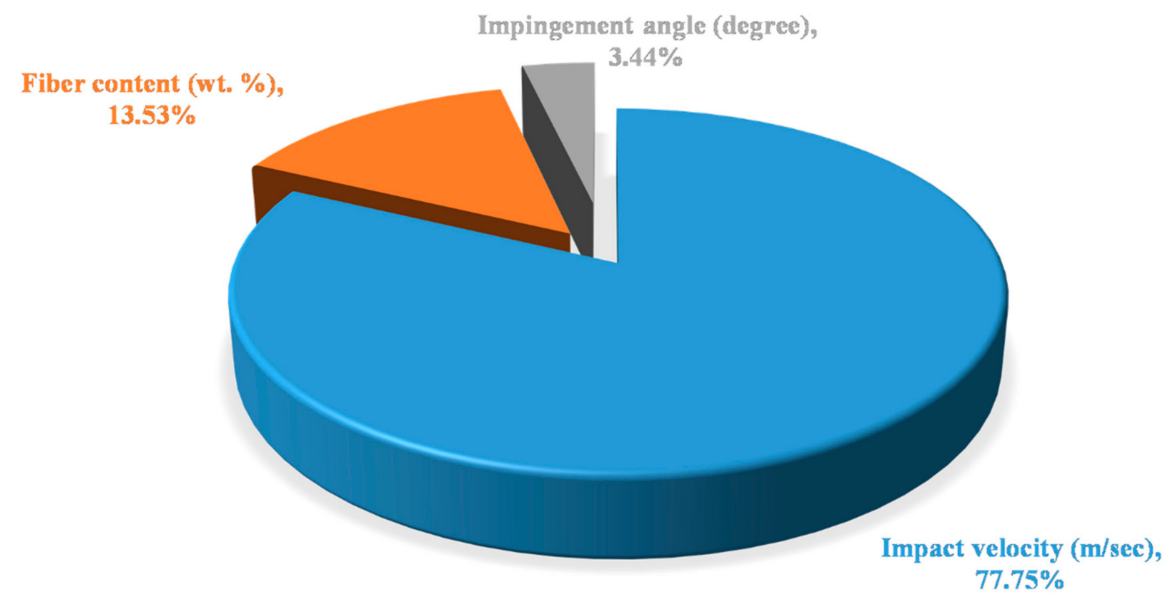

Figure 9. Contribution chart of factors for polyester based composites.
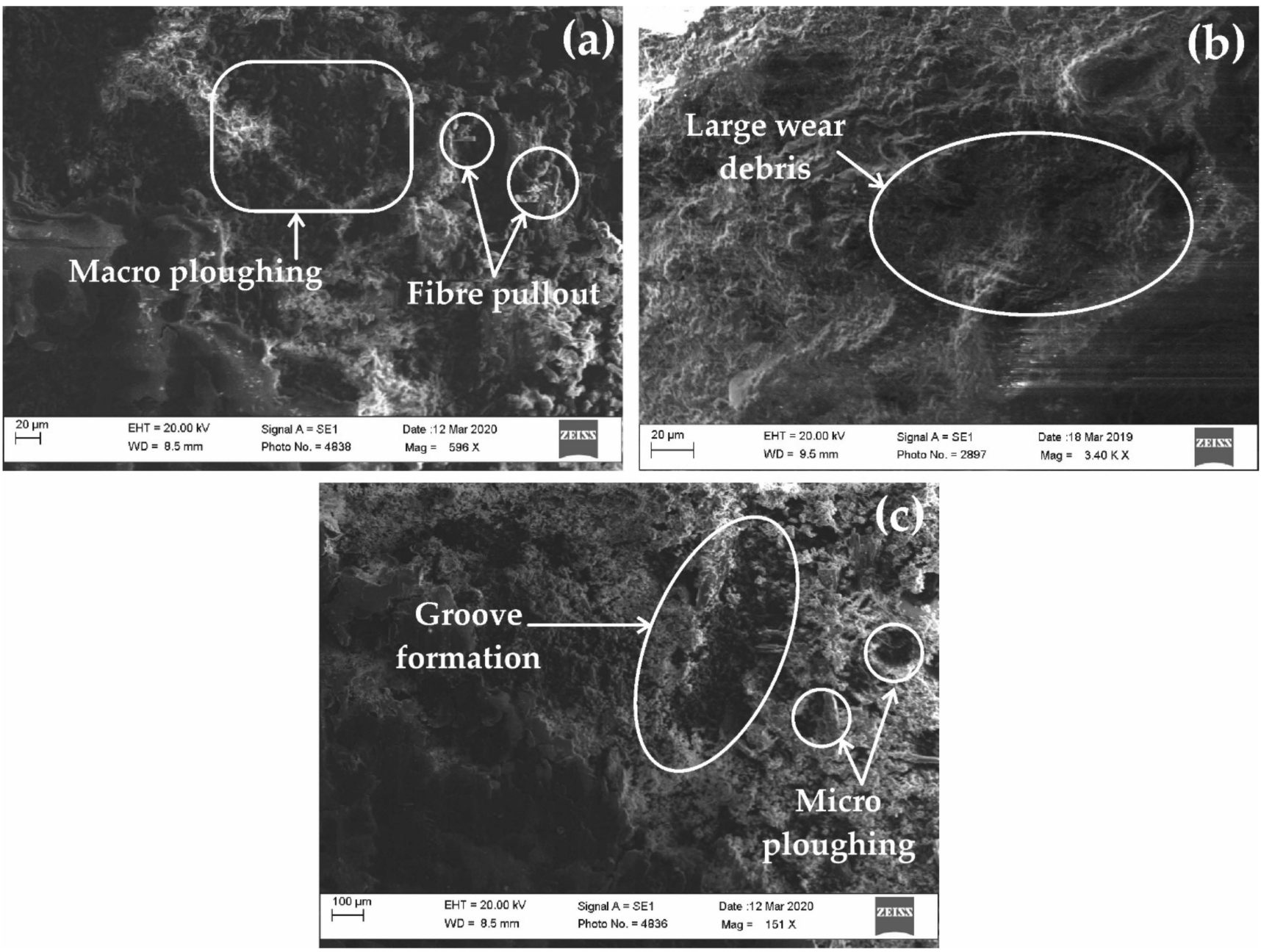

Figure 10. SEM images at highest fiber loading (a) epoxy based composite, (b) vinyl ester and (c) polyester based composite. 
The scientometric analysis emphasizing the highlights especially on several of the most notable biocomposite material findings available in the literary works with a prominence on the biocompatibility, and material characteristics of biocomposites for artificiallimp/prosthetic applications as displayed in the Figure 11. Novel bio-based composites have mostly been evolved in response with a burgeoning consumption for eco-friendly sustainable materials and the willingness to minimise the expenditure with conventional fibres reinforced fossil-fuel derived composites. Investigators had already focused primarily on biocomposites, which are constituted of naturally or synthetic resins derived from the natural fibre-reinforcements. Natural fibres have significant upsides as they are a light-density material which tends to produce comparatively light-weight composites with slightly elevated unique characteristics [63-70]. Such filaments now provide substantial savings, efficient use of resources, and processability, and seems to be a profoundly renewable energy source, aiding to curtail dependence on international as well as household petroleum products. In the current context, self-sustaining environmentally sound approaches to traditional materials, explicitly glass-fibres, are now being deemed to be used in the lamination of artificial-limbs or prostheses connectors.

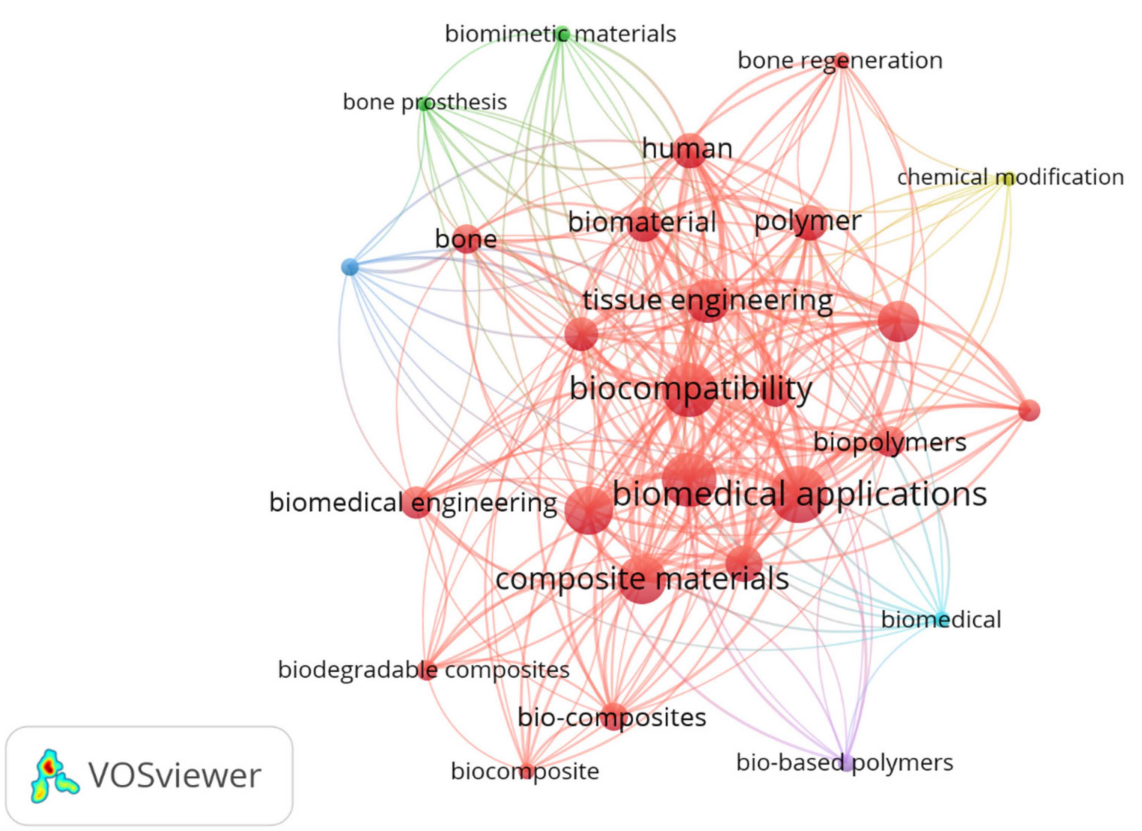

Figure 11. Bibliometric assessment on the applications of natural fiber/synthetic fiber reinforced thermosetting polymeric composites for biomedical and human prosthetic applications.

Utilizing polymer's higher-thermal conversion power-density, delivery methods that rely on these compounds were being used in photo-thermal therapeutic-treatment [71]. The investigators had summarized the findings, emphasized that, whilst area is still very much in beginning phases, conjugated-polymeric/poly-electrolyte interfacial-interactions have vast potential for healthcare applications [71].

Throughout this perspective, one of the most important aspects of sustainable-development is being utilised the organic-matter (biomass), and its compounds as a predecessor of carbonmaterials [72]. A concise summarization of current developments in the synthesizing approach of self-sustaining carbon-compounds and their promising implications has been investigated. This report discusses fundamental observations and crucial recommendations for the eventual development of green carbon-materials and their burgeoning usage in catalytic and healthcare [72].

Metabolism fingerprinting of biological fluids record a wide range of disorders, and urinary-detecting, in particularly, provides ideal non-invasiveness towards upcoming diagnoses [73]. Owing with a restricted bio-markers and higher sampling intricacy, existing 
urinary identification provides major shortcomings and necessitates use of sophisticated materials to extract biomolecular data. Polymer@Ag generated urinary meta-bolic fingerprinting (UMFs) by LDI-MS within seconds employing approximately One Litre of urinary without enriching or purifying [73].

Selective target, trans-membrane distribution, transport, and stimulation responsiveness could all be integrated within peptide-based theranostic nanostructures [74]. Throughout the article, the researchers had discussed generalized principles for synthesising peptide-based therapeutic, and diagnostic nano-materials, with a focus on performance, design, and numerous bio-medical possibilities, and they have illustrated their significant development over the last five years [74].

The developed microchip identifies tiny metabolite-molecules in human plasma rapidly, sensitively, and preferentially without enriching or purifying [75]. On-chip plasma fingerprinting enable further distinction among women having ovarian/colorectal cancer \& control-subjects, and also therapeutic assessment for significant medical surveillance. The research explored the use of laser-de-sorption or ionisation mass-spectroscopy in huge therapeutic medicinal towards vitro-testing [75].

The co-workers have proposed synthesized Palladium-Gold alloys using mass-spectroscopybased metabolite fingerprint, and assessment throughout the diagnostic and radiation treatment of medullo-blastoma [76]. Deep learning has been employed to identify medullo-blastoma individuals, whereas radiation therapy has been observed and an initial array of plasma metabolites-biomarkers was discovered exhibiting progressive alterations [76].

\section{Conclusions}

Natural fiber/synthetic fiber reinforced polymeric composites have been successfully fabricated with three different polymer resins by hand lay-up process for the analysis of erosive wear behavior. Taguchi technique $\mathrm{L}_{16}$ orthogonal array was used to optimize the number of experiments. The obtained results from the investigation revealed that impact velocity is the most significant control factor in the analysis of erosive wear. The second most considerable control was fiber content, followed by impingement angle for all the composites. Polyester-based composites exhibited the highest erosive wear among all the composites, followed by vinyl ester. Epoxy-based composites showed the least erosive wear among all. The contribution charts found that impact velocity has the highest contribution in polyester-based composites, fiber content in vinyl ester composites, and impingement angle in epoxy composites. The morphological analysis exemplified the overarching wear-performance of epoxy-based composites reduced by the interaction of fibers with the contact mating-surface took place by fiber pull-out. Large wear debris was spotted in vinyl ester-based composites as revealed by the SEM analysis. These wear debris formed due to the detachment of sub polymeric material from base material due to low van der wall forces. In case of polyester composites, the examination revealed that main wear mechanism responsible for material removal is groove formation and micro-ploughing. The developed fiber-reinforced polymer sandwich composites are showing significant properties for orthopaedic, bone-fracture fixation applications. The present work can also be investigated for various other polymers such as PE, PC, PLA and PHB for further new possibilities of the composite for better performance. Fillers such as dolomite and marble dust powder can also be added in the composite to further enhance the erosive behaviour of the present composite.

Author Contributions: Conceptualization, J.M.K., S.D., B.G., L.R. and S.S.; Methodology, J.M.K., S.D., B.G., L.R. and S.S.; Formal Analysis, J.M.K., S.D., B.G., L.R. and S.S.; Investigation, J.M.K., S.D., B.G., L.R. and S.S.; Writing—Original Draft Preparation, J.M.K., S.D., B.G., L.R. and S.S.; Writing-Review and editing, S.S., M.R.M.H., R.A.I., S.P.D., S.C., H.C.K. and C.L.; Supervision, J.M.K., S.D., B.G., L.R. and S.S.; Software, J.M.K. and S.S.; Funding acquisition, S.S., M.R.M.H. and R.A.I. All authors have read and agreed to the published version of the manuscript.

Funding: The article processing fee of this manuscript is funded by Research Management Centre, Univesiti Putra Malaysia. 
Institutional Review Board Statement: Not applicable.

Informed Consent Statement: Not applicable.

Data Availability Statement: The data presented in this study are available on request from the corresponding author.

Conflicts of Interest: The authors declare no conflict of interest.

\section{References}

1. Asim, M.; Jawaid, M.; Saba, N.; Nasir, M.; Sultan, M.T.H. Processing of hybrid polymer composites-A review. In Hybrid Polymer Composite Materials; Elsevier: Amsterdam, The Netherlands, 2017; pp. 1-22.

2. Kumar, S.; Mer, K.K.S.; Gangil, B.; Patel, V.K. Synergistic effect of hybrid Himalayan Nettle/Bauhinia-vahlii fibers on physicomechanical and sliding wear properties of epoxy composites. Def. Technol. 2020, 16, 762-776. [CrossRef]

3. Andrady, A.L.; Pandey, K.K.; Heikkilä, A.M. Interactive effects of solar UV radiation and climate change on material damage. Photochem. Photobiol. Sci. 2019, 18, 804-825. [CrossRef]

4. Baig, Z.; Mamat, O.; Mustapha, M. Recent progress on the dispersion and the strengthening effect of carbon nanotubes and graphene-reinforced metal nanocomposites: A review. Crit. Rev. Solid State Mater. Sci. 2018, 43, 1-46. [CrossRef]

5. Lalit, R.; Mayank, P.; Ankur, K. Natural Fibers and Biopolymers Characterization: A Future Potential Composite Material. Stroj. Cas. J. Mech. Eng. 2018, 68, 33-50. [CrossRef]

6. Karami, P.; Khasraghi, S.S.; Hashemi, M.; Rabiei, S.; Shojaei, A. Polymer/nanodiamond composites-A comprehensive review from synthesis and fabrication to properties and applications. Adv. Colloid Interface Sci. 2019, 269, 122-151. [CrossRef]

7. Mudenur, C.; Mondal, K.; Singh, U.; Katiyar, V. Production of Polyhydroxyalkanoates and Its Potential Applications. In Advances in Sustainable Polymers; Springer: Singapore, 2019; pp. 131-164.

8. Rajak, D.; Pagar, D.; Menezes, P.; Linul, E. Fiber-Reinforced Polymer Composites: Manufacturing, Properties, and Applications. Polymers 2019, 11, 1667. [CrossRef] [PubMed]

9. Gangil, B.; Ranakoti, L.; Verma, S.; Singh, T.; Kumar, S. Natural and Synthetic Fibers for Hybrid Composites. In Hybrid Fiber Composites: Materials, Manufacturing, Process Engineering; John Wiley \& Sons: New York, NY, USA, 2020; pp. 1-15.

10. Kureemun, U.; Ravandi, M.; Tran, L.Q.N.; Teo, W.S.; Tay, T.E.; Lee, H.P. Effects of hybridization and hybrid fibre dispersion on the mechanical properties of woven flax-carbon epoxy at low carbon fibre volume fractions. Compos. Eng. 2018, 134, 28-38. [CrossRef]

11. Nagarajaganesh, B.; Rekha, B. Intrinsic cellulosic fiber architecture and their effect on the mechanical properties of hybrid composites. Arch. Civ. Mech. Eng. 2020, 20, 125. [CrossRef]

12. Ramnath, B.V.; Kokan, S.J.; Raja, R.N.; Sathyanarayanan, R.; Elanchezhian, C.; Prasad, A.R.; Manickavasagam, V.M. Evaluation of mechanical properties of abaca-jute-glass fibre reinforced epoxy composite. Mater. Des. 2013, 51, 357-366. [CrossRef]

13. Bhoopathi, R.; Ramesh, M.; Deepa, C. Fabrication and Property Evaluation of Banana-Hemp-Glass Fiber Reinforced Composites. Procedia Eng. 2014, 97, 2032-2041. [CrossRef]

14. Gairola, S.P.; Tyagi, Y.K.; Gangil, B.; Sharma, A. Fabrication and mechanical property evaluation of non-woven banana fibre epoxy-based polymer composite. Mater. Today Proc. 2021, 44, 3990-3996. [CrossRef]

15. Burks, B.; Armentrout, D.; Kumosa, M. Characterization of the fatigue properties of a hybrid composite utilized in high voltage electric transmission. Compos. Appl. Sci. Manuf. 2011, 42, 1138-1147. [CrossRef]

16. Singh, N.P.; Aggarwal, L.; Gupta, V.K. Tensile Behavior of Sisal/Hemp Reinforced High Density Polyethylene Hybrid Composite. Mater. Today Proc. 2015, 2, 3140-3148. [CrossRef]

17. Ranakoti, L.; Rakesh, P.K. Physio-mechanical characterization of tasar silk waste/jute fiber hybrid composite. Compos. Commun. 2020, 22, 100526. [CrossRef]

18. Yahaya, R.; Sapuan, S.M.; Jawaid, M.; Leman, Z.; Zainudin, E.S. Mechanical performance of woven kenaf-Kevlar hybrid composites. J. Reinf. Plast. Compos. 2014, 33, 2242-2254. [CrossRef]

19. Yahaya, R.; Sapuan, S.M.; Jawaid, M.; Leman, Z.; Zainudin, E.S. Effect of layering sequence and chemical treatment on the mechanical properties of woven kenaf-aramid hybrid laminated composites. Mater. Des. 2015, 67, 173-179. [CrossRef]

20. Jawaid, M.; Khalil, H.P.S.A. Cellulosic/synthetic fibre reinforced polymer hybrid composites: A review. Carbohydr. Polym. 2011, 86, 1-18. [CrossRef]

21. Sathishkumar, T.P.; Satheeshkumar, S.; Naveen, J. Glass fiber-reinforced polymer composites-A review. J. Reinf. Plast. Compos. 2014, 33, 1258-1275. [CrossRef]

22. Raghavendra Rao, H.; Varada Rajulu, A.; Ramachandra Reddy, G.; Hemachandra Reddy, K. Flexural and compressive properties of bamboo and glass fiber-reinforced epoxy hybrid composites. J. Reinf. Plast. Compos. 2010, 29, 1446-1450. [CrossRef]

23. Naidu, V.N.P.; Reddy, G.R.; Kumar, M.A.; Reddy, M.M.; Khanam, P.N.; Naidu, S.V. Compressive \& impact properties of sisal/glass fiber reinforced hybrid composites. Int. J. Fibre Text. Res. 2011, 1, 11-14.

24. Almaadeed, M.A.; Kahraman, R.; Khanam, P.N.; Madi, N. Date palm wood flour/glass fibre reinforced hybrid composites of recycled polypropylene: Mechanical and thermal properties. Mater. Des. 2012, 42, 289-294. [CrossRef] 
25. Manjunatha, C.M.; Bojja, R.; Jagannathan, N.; Kinloch, A.J.; Taylor, A.C. Enhanced fatigue behavior of a glass fiber reinforced hybrid particles modified epoxy nanocomposite under WISPERX spectrum load sequence. Int. J. Fatigue 2013, 54, 25-31. [CrossRef]

26. Zhang, Y.; Li, Y.; Ma, H.; Yu, T. Tensile and interfacial properties of unidirectional flax/glass fiber reinforced hybrid composites. Compos. Sci. Technol. 2013, 88, 172-177. [CrossRef]

27. Amuthakkannan, P.; Manikandan, V.; Uthayakumar, M. Mechanical properties of basalt and glass fiber reinforced polymer hybrid composites. J. Adv. Microsc. Res. 2014, 9, 44-49. [CrossRef]

28. Vinayagamoorthy, R.; Rajeswari, N. Mechanical performance studies on Vetiveria zizanioides/jute/glass fiber-reinforced hybrid polymeric composites. J. Reinf. Plast. Compos. 2014, 33, 81-92. [CrossRef]

29. Sanjay, M.R.; Yogesha, B. Studies on Mechanical Properties of Jute/E-Glass Fiber Reinforced Epoxy Hybrid Composites. J. Miner. Mater. Charact. Eng. 2016, 4, 15-25. [CrossRef]

30. Haque, M.M.; Hasan, M. Influence of fiber surface treatment on physico-mechanical properties of betel nut and glass fiber reinforced hybrid polyethylene composites. Adv. Mater. Process. Technol. 2018, 4, 511-525. [CrossRef]

31. Sosiati, H.; Shofie, Y.A.; Nugroho, A.W. Tensile properties of Kenaf/E-glass reinforced hybrid polypropylene (PP) composites with different fiber loading. Evergr. Jt. J. Nov. Carbon Resour. Sci. Green Asia Strategy 2018, 5, 1-5. [CrossRef]

32. Mittal, M.; Chaudhary, R. Development of PALF/Glass and COIR/Glass fiber reinforced hybrid epoxy composites. J. Mater. Sci. Surf. Eng. 2018, 6, 851-861.

33. Arumugam, S.; Kandasamy, J.; Shah, A.U.M.; Sultan, M.T.H.; Safri, S.N.A.; Majid, M.S.A.; Basri, A.A.; Mustapha, F. Investigations on the Mechanical Properties of Glass Fiber/Sisal Fiber/Chitosan Reinforced Hybrid Polymer Sandwich Composite Scaffolds for Bone Fracture Fixation Applications. Polymers 2020, 12, 1501. [CrossRef]

34. Prabhu, L.; Krishnaraj, V.; Sathish, S.; Gokulkumar, S.; Karthi, N. Study of mechanical and morphological properties of jute-tea leaf fiber reinforced hybrid composites: Effect of glass fiber hybridization. Mater. Today Proc. 2020, 27, 2372-2375. [CrossRef]

35. Ramesh, M.; Palanikumar, K.; Reddy, K.H. Evaluation of Mechanical and Interfacial Properties of Sisal/Jute/Glass Hybrid Fiber Reinforced Polymer Composites. Trans. Indian Inst. Met. 2016, 69, 1851-1859. [CrossRef]

36. Prabhu, L.; Krishnaraj, V.; Gokulkumar, S.; Sathish, S.; Sanjay, M.R.; Siengchin, S. Mechanical, chemical and sound absorption properties of glass/kenaf/waste tea leaf fiber-reinforced hybrid epoxy composites. J. Ind. Text. 2020, 1528083720957392. [CrossRef]

37. Vigneshwaran, S.; Uthayakumar, M.; Arumugaprabu, V. A review on erosion studies of fiber-reinforced polymer composites. J. Reinf. Plast. Compos. 2017, 36, 1019-1027. [CrossRef]

38. Öztürk, B.; Gedikli, H.; Kılıçarslan, Y.S. Erosive wear characteristics of E-glass fiber reinforced silica fume and zinc oxide-filled epoxy resin composites. Polym. Compos. 2020, 41, 326-337. [CrossRef]

39. Choudhary, M.; Singh, T.; Dwivedi, M.; Patnaik, A. Waste marble dust-filled glass fiber-reinforced polymer composite Part I: Physical, thermomechanical, and erosive wear properties. Polym. Compos. 2019, 40, 4113-4124. [CrossRef]

40. Karsli, N.G.; Yilmaz, T.; Aytac, A.; Ozkoc, G. Investigation of erosive wear behavior and physical properties of SGF and/or calcite reinforced ABS/PA6 composites. Compos. Eng. 2013, 44, 385-393. [CrossRef]

41. Choudhary, M.; Sharma, A.; Agarwal, P.; Singh, T.; Patnaik, T.; Patnaik, A. Experimental and numerical investigation of mechanical and erosion behavior of barium sulphate filled glass fiber reinforced polymer composites. Polym. Compos. 2021, 42 , 753-773. [CrossRef]

42. Mohan, N.; Mahesha, C.R.; Rajaprakash, B.M. Erosive Wear Behaviour of WC Filled Glass Epoxy Composites. Procedia Eng. 2013, 68, 694-702. [CrossRef]

43. Nayak, S.; Mohanty, J. Erosion wear behavior of benzoyl chloride modified areca sheath fiber reinforced polymer composites. Compos. Commun. 2020, 18, 19-25. [CrossRef]

44. Qian, D.; Bao, L.; Takatera, M.; Kemmochi, K.; Yamanaka, A. Fiber-reinforced polymer composite materials with high specific strength and excellent solid particle erosion resistance. Wear 2010, 268, 637-642. [CrossRef]

45. Verma, S.K.; Gupta, A.; Singh, T.; Gangil, B.; Jánosi, E.; Fekete, G. Influence of dolomite on mechanical, physical and erosive wear properties of natural-synthetic fiber reinforced epoxy composites. Mater. Res. Express 2019, 6, 125704. [CrossRef]

46. Jha, A.K.; Mantry, S.; Satapathy, A.; Patnaik, A. Erosive Wear Performance Analysis of Jute-Epoxy-SiC Hybrid Composites. J. Compos. Mater. 2010, 44, 1623-1641.

47. Kaundal, R.; Patnaik, A.; Satapathy, A. Mechanical characterizations and development of erosive wear model for $\mathrm{Al}_{2} \mathrm{O}_{3}$-filled short glass fiber-reinforced polymer composites. Proc. Inst. Mech. Eng. J. Mater. Des. Appl. 2018, 232, 893-908. [CrossRef]

48. Panda, P.; Mantry, S.; Mohapatra, S.; Singh, S.K.; Satapathy, A. A study on erosive wear analysis of glass fiber-epoxy-AlN hybrid composites. J. Compos. Mater. 2014, 48, 107-118. [CrossRef] 
49. Singh, T.; Tejyan, S.; Patnaik, A.; Singh, V.; Zsoldos, I.; Fekete, G. Fabrication of waste bagasse fiber-reinforced epoxy composites: Study of physical, mechanical, and erosion properties. Polym. Compos. 2019, 40, 3777-3786. [CrossRef]

50. Tejyan, S.; Singh, T.; Patnaik, A.; Fekete, G.; Gangil, B. Physico-mechanical and erosive wear analysis of polyester fibre-based nonwoven fabric-reinforced polymer composites. J. Ind. Text. 2019, 49, 447-464. [CrossRef]

51. Kar, J.; Rout, A.K.; Sutar, A.K. Physical, Mechanical, and Erosion Characterization of Palm Leaf Stalk Fiber Reinforced Epoxy Composites Filled with Palm Leaf Stem Stalk (PLSS) Powder. BioResources 2018, 13, 7212-7231. [CrossRef]

52. Patnaik, A.; Satapathy, A.; Mahapatra, S.S.; Dash, R.R. Implementation of Taguchi Design for Erosion of Fiber-Reinforced Polyester Composite Systems with SiC Filler. J. Reinf. Plast. Compos. 2008, 27, 1093-1111. [CrossRef]

53. Kumar, S.; Prasad, L.; Kumar, S.; Patel, V.K. Physico-mechanical and Taguchi-designed sliding wear properties of Himalayan agave fiber reinforced polyester composite. J. Mater. Res. Technol. 2019, 8, 3662-3671. [CrossRef]

54. Patnaik, A.; Satapathy, A.; Mahapatra, S.S.; Dash, R.R. Erosive Wear Assessment of Glass Reinforced Polyester-Flyash Composites Using Taguchi Method. Int. Polym. Process. 2008, 23, 192-199. [CrossRef]

55. Khare, J.M.; Dahiya, S.; Gangil, B.; Ranakoti, L. Influence of different resins on Physico-Mechanical properties of hybrid fiber reinforced polymer composites used in human prosthetics. Mater. Today Proc. 2021, 38, 345-349. [CrossRef]

56. Islam, M.S.; Pickering, K.L.; Foreman, N.J. The Effect of Accelerated Weathering on the Mechanical Properties of Alkali Treated Hemp Fibre/Epoxy Composites. J. Adhes. Sci. Technol. 2011, 25, 1947-1959. [CrossRef]

57. Sethi, S.; Ray, B.C. Environmental effects on fibre reinforced polymeric composites: Evolving reasons and remarks on interfacial strength and stability. Adv. Colloid Interface Sci. 2015, 217, 43-67. [CrossRef]

58. Rout, A.; Satapathy, A.; Mantry, S.; Sahoo, A.; Mohanty, T. Erosion Wear Performance Analysis of Polyester-GF-Granite Hybrid Composites using the Taguchi Method. Procedia Eng. 2012, 38, 1863-1882. [CrossRef]

59. Chohan, J.S.; Mittal, N.; Kumar, R.; Singh, S.; Sharma, S.; Dwivedi, S.P.; Saxena, A.; Chattopadhyaya, S.; Ilyas, R.A.; Le, C.H.; et al. Optimization of FFF Process Parameters by Naked Mole-Rat Algorithms with Enhanced Exploration and Exploitation Capabilities. Polymers 2021, 13, 1702. [CrossRef]

60. Ilyas, R.A.; Sapuan, S.M.; Asyraf, M.R.M.; Dayana, D.A.Z.N.; Amelia, J.J.N.; Rani, M.S.A.; Norrrahim, M.N.F.; Nurazzi, N.M.; Aisyah, H.A.; Sharma, S.; et al. Polymer Composites Filled with Metal Derivatives: A Review of Flame Retardants. Polymers 2021, 13, 1701. [CrossRef]

61. Chohan, J.S.; Mittal, N.; Kumar, R.; Singh, S.; Sharma, S.; Singh, J.; Rao, K.V.; Mia, M.; Pimenov, D.Y.; Dwivedi, S.P. Mechanical Strength Enhancement of 3D Printed Acrylonitrile Butadiene Styrene Polymer Components Using Neural Network Optimization Algorithm. Polymers 2020, 12, 2250. [CrossRef]

62. Singh, Y.; Singh, J.; Sharma, S.; Aggarwal, V.; Pruncu, C.I. Multi-objective Optimization of Kerf-taper and Surface-roughness Quality Characteristics for Cutting-operation On Coir and Carbon Fibre Reinforced Epoxy Hybrid Polymeric Composites During $\mathrm{CO}_{2}$-Pulsed Laser-cutting Using RSM. Lasers Manuf. Mater. Process 2021, 8, 157-182. [CrossRef]

63. Sharma, S.; Singh, J.; Kumar, H.; Sharma, A.; Aggarwal, V.; Gill, A.; Jayarambabu, N.; Kailasa, S.; Rao, K. Utilization of rapid prototyping technology for the fabrication of an orthopedic shoe inserts for foot pain reprieve using thermo-softening viscoelastic polymers: A novel experimental approach. Meas. Control 2020, 53, 519-530. [CrossRef]

64. Singh, Y.; Singh, J.; Sharma, S.; Sharma, A.; Chohan, J.S. Process Parameter Optimization in Laser Cutting of Coir Fiber Reinforced Epoxy Composite-A Review. Mater. Today Proc. 2021, in press. [CrossRef]

65. Chohan, J.S.; Kumar, R.; Singh, T.B.; Singh, S.; Sharma, S.; Singh, J.; Mia, M.; Pimenov, D.Y.; Chattopadhyaya, S.; Dwivedi, S.P.; et al. Taguchi S/N and TOPSIS Based Optimization of Fused Deposition Modelling and Vapor Finishing Process for Manufacturing of ABS Plastic Parts. Materials 2020, 13, 5176. [CrossRef] [PubMed]

66. Prabhakaran, S.; Vijayan, K.; Sharma, S.; Mouleeswaran, S.K.; Ramasamy, J.K.; Redoune, Z. Experimental study on thermal and morphological analysis of Green composite sandwich made of Flax and agglomerated cork. J. Therm. Anal. Calorim. 2020, 139, 3003-3012. [CrossRef]

67. Sharma, S.; Sudhakara, P.; Singh, J.; Ilyas, R.A.; Asyraf, M.R.M.; Razman, M.R. Critical Review of Biodegradable and Bioactive Polymer Composites for Bone Tissue Engineering and Drug Delivery Applications. Polymers 2021, 13, 2623. [CrossRef] [PubMed]

68. Sharma, S.; Sudhakara, P.; Omran, A.A.B.; Singh, J.; Ilyas, R.A. Recent Trends and Developments in Conducting Polymer Nanocomposites for Multifunctional Applications. Polymers 2021, 13, 2898. [CrossRef] [PubMed]

69. Jha, K.; Tyagi, Y.K.; Kumar, R.; Sharma, S.; Huzaifah, M.R.M.; Li, C.; Ilyas, R.A.; Dwivedi, S.P.; Saxena, A.; Pramanik, A. Assessment of Dimensional Stability, Biodegradability, and Fracture Energy of Bio-Composites Reinforced with Novel Pine Cone. Polymers 2021, 13, 3260. [CrossRef]

70. Kadier, B.; Ilyas, R.A.; Huzaifah, M.R.M.; Harihastuti, N.; Sapuan, S.M.; Harussani, N.M.; Azlin, M.N.M.; Yuliasni, R.; Ibrahim, R.; Atikah, M.S.N.; et al. Use of Industrial Wastes as Sustainable Nutrient Sources for Bacterial Cellulose (BC) Production: Mechanism, Advances, and Future Perspectives. Polymers 2021, 19, 3365. [CrossRef] [PubMed]

71. Jephcott, L.; Eslami, M.; Travaglini, L.; Lauto, A.; Mawad, D. A conjugated polymer-liposome complex: A contiguous water-stable, electronic, and optical interface. View 2020, 2, 20200081. [CrossRef]

72. Lan, G.; Yang, J.; Ye, R.-P.; Boyjoo, Y.; Liang, J.; Liu, X.; Li, Y.; Liu, J.; Qian, K. Sustainable Carbon Materials toward Emerging Applications. Small Methods 2021, 5, 2001250. [CrossRef] 
73. Yang, J.; Wang, R.; Huang, L.; Zhang, M.; Niu, J.; Bao, C.; Shen, N.; Dai, M.; Guo, Q.; Wang, Q.; et al. Urine metabolic fingerprints encode subtypes of kidney diseases. Angew. Chem. Int. Ed. 2020, 59, 1703. [CrossRef]

74. Rong, L.; Lei, Q.; Zhang, X.-Z. Recent advances on peptide-based theranostic nanomaterials. View 2020, 1, 20200050. [CrossRef]

75. Shu, W.; Wang, Y.; Liu, C.; Li, R.; Pei, C.; Lou, W.; Lin, S.; Di, W.; Wan, J. Construction of a Plasmonic Chip for Metabolic Analysis in Cervical Cancer Screening and Evaluation. Small Methods 2020, 4, 1900469. [CrossRef]

76. Cao, J.; Shi, X.; Gurav, D.D.; Huang, L.; Su, H.; Li, K.; Niu, J.; Zhang, M.; Wang, Q.; Jiang, M.; et al. Medulloblastoma: Metabolic Fingerprinting on Synthetic Alloys for Medulloblastoma Diagnosis and Radiotherapy Evaluation. Adv. Mater. 2020, $32,2070178$. [CrossRef] 